\title{
THE EVOLVING FIELD OF BIODEFENCE: THERAPEUTIC DEVELOPMENTS AND DIAGNOSTICS
}

\author{
James C. Burnett ${ }^{*}$, Erik A. Henchal ${ }^{\sharp}$, Alan L. Schmaljohn ${ }^{*}$ and Sina Bavari
}

Abstract | The threat of bioterrorism and the potential use of biological weapons against both military and civilian populations has become a major concern for governments around the world. For example, in 2001 anthrax-tainted letters resulted in several deaths, caused widespread public panic and exerted a heavy economic toll. If such a small-scale act of bioterrorism could have such a huge impact, then the effects of a large-scale attack would be catastrophic. This review covers recent progress in developing therapeutic countermeasures against, and diagnostics for, such agents.

BACILLUS ANTHRACIS The causative agent of anthrax and a Gram-positive, sporeforming bacillus. This aerobic organism is non-motile, catalase positive and forms large, grey-white to white, nonhaemolytic colonies on sheep blood agar plates.

\author{
${ }^{*}$ Developmental \\ Therapeutics Program, \\ Target Structure-Based \\ Drug Discovery Group, \\ National Cancer \\ Institute-SAIC, Frederick, \\ Maryland 21702, USA. \\ ${ }^{\ddagger}$ United States Army Medical \\ Research Institute of \\ Infectious Diseases, \\ Frederick, Maryland \\ 21702, USA. \\ Correspondence to S.B. \\ e-mail: \\ sina.bavari@amedd.army. \\ mil/bavaris@ncifcrf.gov \\ doi:10.1038/nrd1694
}

Microorganisms and toxins with the greatest potential for use as biological weapons have been categorized using the scale A-C by the Centers for Disease Control and Prevention (CDC). This review covers the discovery and challenges in the development of therapeutic countermeasures against select microorganisms and toxins from these categories. We also cover existing antibiotic treatments, and early detection and diagnostic strategies for intervening against these biothreat agents at a point in disease progression when the prognosis can still be influenced; and to guide the selection of the optimum therapeutic protocols. Furthermore, although a detailed review of vaccines for biothreat agents exceeds the scope of this manuscript, an important point to consider is that the described therapeutics will most likely be used in combination with vaccines, which possess the advantage of providing long-term immuno-protection.

\section{Countering biological toxins}

Research to identify/develop therapeutics against biological toxins falls into two categories: relatively large biological inhibitors, such as antibodies and decoy proteins; and small-molecule inhibitors (both peptidic and non-peptidic). The identification and development of therapeutics against anthrax toxin, botulinum neurotoxins, ricin toxin and staphylococcal enterotoxins are discussed. This section is limited mainly to small-molecule inhibitors, and a brief review of antibody development and design against biotoxins is mentioned in TABLE 1.

Anthrax toxin. The toxin secreted by BACILLUS ANTHRACIS, ANTHRAX TOXIN (ATX), possesses the ability to impair innate and adaptive immune responses ${ }^{1-3}$, which in turn potentiates the bacterial infection. This suggests that inhibiting ATX activity is a viable therapeutic modality — blocking the actions of this toxin should provide the window of opportunity that is necessary for conventional antibiotics, in combination with the inherent immune response, to clear the bacterium well before deadly sepsis and toxic shock occur. FIGURE 1 shows how lethal toxin (LT, which comprises protective antigen (PA) + lethal factor (LF)), attacks cells. The potency of LT is shown in TABLE 2.

The action of ATX can be inhibited in several ways. One method would be to interfere with the furin-mediated cleavage of $\mathrm{PA}$ to its active form $\left(\mathrm{PA}_{63}\right)$ following host-cell receptor binding ${ }^{4-7}$. To this end, hexa-D-arginine has been identified ${ }^{8}$, and has demonstrated the capacity to delay ATX toxaemia in vivo ${ }^{9}$. Following this approach, a more potent nona-D-arginine has been generated ${ }^{10}$.

Non-functional (decoy) PA mutants that co-assemble with wild-type PA, and interfere with LF/oedema factor (EF) transport into the host-cell cytosol, have shown 
ANTHRAX TOXIN

A complex composed of three proteins: protective antigen (PA), lethal factor (LF) and oedema factor $(\mathrm{EF})$.

\section{SNARE COMPLEX}

A complex composed of SNAP25, VAMP (also referred to as synaptobrevin) and syntaxin that is involved in membrane fusion and the exocytosis of acetylcholine into neuromuscular junctions.

\section{Table 1 | Antibodies that target biological toxins}

\begin{tabular}{lllr} 
Target & Source & Comments & References \\
Anthrax toxin & $\begin{array}{l}\text { Human, humanized } \\
\text { and murine }\end{array}$ & $\begin{array}{l}\text { Many have shown protection against both anthrax lethal } \\
\text { toxin and Bacillus anthracis. }\end{array}$ & $180-185$ \\
$\begin{array}{l}\text { Botulinum } \\
\text { neurotoxins }\end{array}$ & $\begin{array}{l}\text { Human, humanized } \\
\text { and murine }\end{array}$ & $\begin{array}{l}\text { Antibodies against all seven serotypes are needed. Some } \\
\text { have been used in combination; affinity might be crucial for } \\
\text { protection. Broad neutralizing antibodies are needed. } \\
\text { Most antibodies are against the carboxyl end of the toxin; } \\
\text { should explore other sites. }\end{array}$ & 186-194 \\
\hline Ricin & Avian and murine & $\begin{array}{l}\text { Have shown protection in vivo. Critical need for high affinity } \\
\text { antibodies. Genetically inactivated ricin can be used as an } \\
\text { antigen. Aerosolized ricin induces lung damage even in } \\
\text { surviving subjects }{ }^{201} \text {. Adjunctive therapeutics are desired. }\end{array}$ & $195-202$ \\
\hline $\begin{array}{l}\text { Staphylococcal } \\
\text { enterotoxins }\end{array}$ & $\begin{array}{l}\text { Human, avian } \\
\text { and murine }\end{array}$ & $\begin{array}{l}\text { Some have shown protection against aerosolized toxin, } \\
\text { need an antibody with broad neutralizing activity against } \\
\text { all staphylococcal enterotoxins. }\end{array}$ & $62,203,204$ \\
\hline
\end{tabular}

promise $^{11,12}$. Another method would involve interfering with PA-LF or PA-EF binding events. A polyvalent compound consisting of a polyacrylamide backbone substituted with multiple copies of a peptide (HTSTYWWLDGAP) provides protection against $\mathrm{LF}^{13}$. Finally, identifying or generating molecules that bind within the PA heptamer pore, thereby blocking LF/EF release into the host-cell cytosol, is also a potential avenue for toxin inhibition. In anticipation of such research, Nguyen ${ }^{14}$ has generated a structurally viable PA heptamer model that will be useful for future drug discovery.

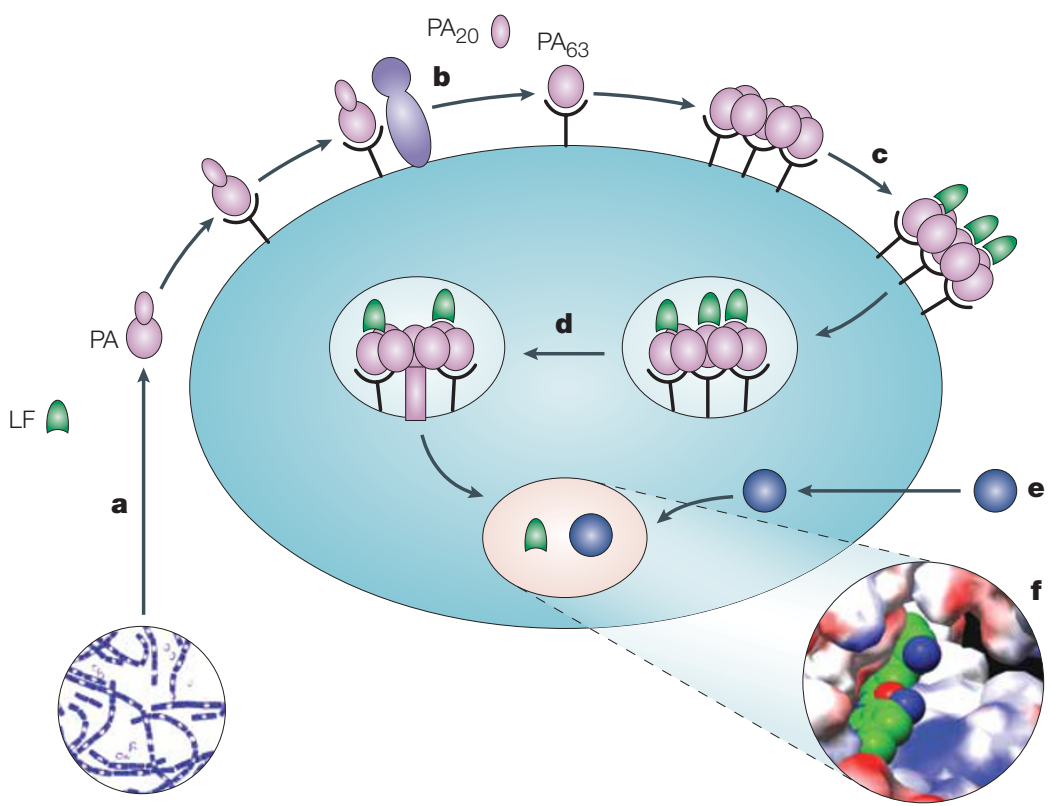

Figure 1 | A schematic of anthrax toxin (ATX) lethal factor cell entry. a $\mid$ ATX is secreted by Bacillus anthracis. $\mathbf{b}$ | The inactive form of protective antigen $\left(\mathrm{PA}_{83}\right)$ binds to a host-cell receptor, where it is cleaved by a furin-related protease, to give active $\mathrm{PA}_{63} . \mathbf{c} \mid P A_{63}$ heptamerizes and can bind to either lethal factor (LF) or oedema factor (EF) (in this depiction the heptamer binds LF). $\mathbf{d}$ | The complex is endocytosed, and LF (as shown) or EF (not shown) translocates from the endosome into the host-cell cytosol. e | Therapeutics, in this example NSC 12155 (REF. 19), are being designed to enter intoxicated cells and inhibit the protease activity of LF. $\mathbf{f} \mid$ A surface depiction of NSC 12155 bound within the LF substrate-binding cleft is shown. The inhibitor carbons are green, nitrogens are blue and oxygens are red. The surface of $L F$ is red for acidic surface, blue for basic surface, and white for neutral surface.
LF has been recognized as one of the main virulence components of B. anthracis. Consequently, there is much interest in identifying inhibitors of this metalloprotease. Several hydroxamate inhibitors of LF have been identified ${ }^{15,16}$, one of which, In-2-LF ${ }^{16}$, has a $K_{\mathrm{i}}=1.0 \mathrm{nM}$ in vitro. By incorporating a metalchelating moiety, a potent inhibitor MKARRKKVYP$\operatorname{NHOH}\left(K_{\mathrm{i}}=0.0011 \mu \mathrm{M}\right)$ was generated ${ }^{17,18}$. Using this information, additional peptidic inhibitors were identified ${ }^{17}$ (TABLE 3). Panchal et al. ${ }^{19}$ used a highthroughput assay to analyse the National Cancer Institute's (NCI's) Diversity Set. Several small (nonpeptidic) molecules with drug-like properties were identified (TABLE 3; FIG. 2a). Some of these compounds were identified via subsequent three-dimensional database mining. On the basis of compounds identified during this study, a common pharmacophore for LF inhibition was generated that will provide a template for identifying new leads. The search for LF inhibitors has also prompted the application of less conventional technologies - for example, a mass spectrometry-based technique was used to identify the inhibitor DS-998 (TABLE 3$)^{20}$. Finally, nature has proven once again to be a pharmaceutical treasure chest: natural products, including epigallocatechin-3gallate $\left(\mathrm{IC}_{50}=97 \mathrm{nM}\right)$, an isolate of green tea (TABLE $3)^{21}$, and aminoglycosides, including neomycin B $\left(K_{i}\right.$ $=7.0 \mathrm{nM})^{22}$, are potent LF inhibitors.

Two notable inhibitors of the adenylate cyclase activity of EF were identified during a screen of the Available Chemical Directory database ${ }^{23}$ (TABLE 4), whereas an active metabolite of adefovir dipivoxil (TABLE 4) was found to selectively inhibit EF with high affinity ${ }^{24}$.

Botulinum neurotoxins. Botulinum neurotoxins (BoNTs) are the most potent of the biological toxins (TABLE 2), are easily produced and can be delivered via an aerosol route ${ }^{25}$. There are seven BoNT serotypes (A-G), and each cleaves a specific component of the soluble $\mathrm{N}$-ethylmaleimide-sensitive factor attachment protein receptor SNARE COMPLEX. This cleavage impairs the release of acetylcholine, and can lead to deadly flaccid paralysis. The toxin is composed of a heavy chain 


\begin{tabular}{lll}
\hline \multicolumn{3}{l}{ Table 2 | Comparative biological potency of biodefence toxins } \\
\hline Toxin & LD $_{50}$ ( $\mathbf{l g}$ per $\left.\mathbf{k g}\right)$ & Source \\
\hline Botulinum toxin A & 0.001 & Bacterium \\
\hline Tetanus toxin & 0.002 & Bacterium \\
\hline Shiga toxin & 0.002 & Bacterium \\
\hline Staphlococcal enterotoxin B & $0.02^{*}$ & Bacterium \\
\hline Diptheria toxin & 0.1 & Bacterium \\
\hline Maitotoxin & 0.1 & Marine dinoflagellate \\
\hline Ciguatoxin (P-CTX-1) & 0.2 & Marine dinoflagellate abrin \\
\hline Batrachotoxin & 0.7 & plant \\
\hline Ricin & 2 & Poison arrow frog \\
\hline Tetrodotoxin & 3 & Plant \\
\hline Saxitoxin & 8 & Pufferfish \\
\hline Staphylococcal & 10 & Marine dinoflagellate \\
eneterotoxin B & 10 (aerosol & Bacterium \\
\hline Anthrax lethal toxin & nonhuman primates) & \\
\hline Microcystin & $50^{\ddagger}$ & Bacterium \\
\hline Aconitine & 50 & Blue-green algae \\
\hline T-2 toxin & 100 & Plant \\
\hline
\end{tabular}

*Predicted human aerosol. *Based on rat model of anthrax PA and LF toxicity. REF. 25 provides an excellent review on inhaled biological toxins. Table adapted from REF. 206.

RICIN TOXIN

Isolated from seeds of the castor plant (Ricinus communis), ricin toxin consists of a $32-\mathrm{kDa} B$ chain that is linked by a disulphide bridge to a $32-\mathrm{kDa} A$ chain (RTA) ${ }^{175,176}$. The B chain binds cell surfaces. Once inside the cell cytoplasm, RTA is released, and irreversibly depurinates the $28 \mathrm{~S}$ rRNA, destroying the elongationfactor-binding site, and thereby disabling cellular protein synthesis $^{177,178,179}$.

STAPHYLOCOCCAL ENTEROTOXINS

A large group of protein toxins that engage both major histocompatibility complex class II molecules on the surface of antigen-presenting cells and the variable $(V) \beta$-chain of a large subset of T-cell receptors.
(HC) that targets gangliosidic receptors on nerve terminals, forms a low- $\mathrm{pH}$ endosome and translocates the light chain (LC) into the nerve cytosol ${ }^{26-28}$. The LC acts as a zinc metalloprotease, and is responsible for SNARE protein cleavage $\mathrm{e}^{29-31}$. The $\mathrm{HC}$ and the LC therefore provide two viable targets for neutralizing this toxin. The vast majority of research to identify BoNT therapeutics has focused on serotypes $\mathrm{A}$ and $\mathrm{B}$. With regard to inhibiting $\mathrm{HC}$ activity, Deshpande et al. ${ }^{32}$ and Sheridan et al..$^{33}$ have proposed that several antimalarial compounds, which delay muscle paralysis following BoNT serotype A (BoNT/A) challenge, act by interfering with the acidity of the toxin-mediated endosome. In addition, Eswaramoorthy et al. ${ }^{34}$ have generated a co-crystal structure of doxorubicin bound within the BoNT serotype B (BoNT/B) HC ganglioside-binding site. Such inhibitors would interfere with the ability of the toxin to bind to its neuronal receptor.

LC inhibitors would be crucial to rescuing nerve activity after toxin internalization. In the search for such therapeutics, a number of short 'hinge' peptide inhibitors of the BoNT/A LC have been described ${ }^{35}$. However, the structures of these hinge peptides were not deconvoluted from the test mixtures. Using a substrate-to-inhibitor strategy, Schmidt and co-workers ${ }^{36-39}$ generated potent inhibitors of the BoNT/A LC (TABLE 5). Subsequently, a similar strategy was used by Sukonpan et al..$^{40}$ to identify additional peptidic inhibitors. In a recent study ${ }^{41}$, small (non-peptidic and non-chelating) drug-like molecules that inhibit the BoNT/A LC were discovered (TABLE 5). Two of the most potent inhibitors, michellamine B and Q2-15 (FIG. 2b), are shown in TABLE 5. On the basis of the identified inhibitors and molecular docking using LCs obtained from available $\mathrm{X}$-ray crystal structures ${ }^{42,43}$, a pharmacophore for BoNT/A LC inhibition was generated ${ }^{41}$ that will be of value for ongoing drug discovery. Furthermore, Breidenbach and Brunger ${ }^{44}$ have recently solved the X-ray co-crystal structure of BoNT/A LC complexed with residues 141-204 of synaptosomal-associated protein 25 (SNAP25). This important structure reveals substrate-recognition exosites that could be exploited for inhibitor design. Toosendanin ${ }^{45}$, a triterpenoid natural product, might act at such an exosite.

The majority of compounds that inhibit BoNT/B metalloprotease activity are pseudo-peptidic in nature. However, two non-peptidic inhibitors have been described ${ }^{46,47}$ (TABLE 6). With regard to pseudopeptides, phosphoramidon and three of its synthetic derivatives were found to be weak inhibitors ${ }^{48}$, whereas buforin I has also shown activity against the BoNT/B LC ${ }^{49}$. Recently, a Cys-containing peptide inhibitor was also reported ${ }^{50}$. The most effective pseudo-peptide BoNT/B LC inhibitors to date were identified during the course of several complementary studies. Initially, a series of pseudo-tripeptides with nominal $K_{\mathrm{i}}$ values were generated ${ }^{51}$. In subsequent publications ${ }^{52,53}$, side-chain modifications produced more potent inhibitors (TABLE 6$)^{53}$. In the latest study, the pseudo-tripeptide inhibitors were subjected to minor structural changes, and several compounds with $K_{\mathrm{i}}$ values ranging from $2.3 \mathrm{nM}$ to $5.4 \mathrm{nM}$ where generated, with a symmetrical disulphide derivative displaying the greatest potency (TABLE 6) ${ }^{54}$.

With regard to the BoNT serotype F LC, Schmidt and Stafford recently generated a potent peptidic inhibitor composed of VAMP residues 22-58 (J. J. Schmidt and R. G. Stafford, personal communication).

Ricin toxin. The potency of RICIN TOXIN is show in TABLE 2. In preparation for inhibitor development, Monzingo and Robertus ${ }^{55}$ solved co-crystal structures of two substrate analogues - formycin monophosphate (FMP) and dinucleotide ApG - bound to the ricin toxin A chain (RTA). Using the FMP-RTA co-crystal as a guide, Yan et al. ${ }^{56}$ identified the pterin-based inhibitors pteroic acid and neopterin (TABLE 7). Both inhibitors were co-crystallized with RTA (FIG. 2c). In a follow-up study ${ }^{57}$, an oxazole-pyrimidine ring system (9OG) (TABLE 7) was also found to inhibit the RTA. Aptamers (nucleic-acid ligand ${ }^{58}$ ) that inhibit the RTA have also been generated. Hesselberth et al. ${ }^{59}$ identified a 31-nucleotide aptamer, whereas Tanaka et al..$^{60}$, using a mechanistic approach ${ }^{61}$, generated a variety of much smaller aptamers containing unnatural sugar and purine derivatives (TABLE 7) ${ }^{60}$.

Staphylococcal enterotoxins. STAPHYLOCOCCAL ENTEROTOXINS (SEs) stimulate a powerful cytokine and immune response, which has earned them the name superantigens (SAgs). FIGURE $2 \mathrm{~d}$ shows the co-crystal of a SAg and a human class II major histocompatibility complex (MHC) molecule. SEs and other related exotoxins have been implicated in various disorders and 
lethal shock syndrome ${ }^{62}$. Many of these exotoxins are relatively easy to produce in large quantities and are remarkably stable. When delivered by aerosol, these agents are highly incapacitating and lethal. Modulating cytokine responses is one of the clear mechanisms to interfere with SE toxicities ${ }^{63,64}$.

Soluble decoy receptor, high-affinity variants of the T-cell receptor (TCR) V $\beta$ region have been engineered to counteract SEs as therapeutic leads ${ }^{65,66}$. Additional studies have now generated $\mathrm{V} \beta$ proteins against several toxins with picomolar affinities (R. Buonpane and D. Kranz, personal communication). Such high affinity might be essential for neutralizing agents such as SAgs, which are highly toxic even at extremely low concentrations.
Although consensus peptides as therapeutics are presently controversial, in some animal models these mimetic peptides have been shown to diminish the toxicity of SAgs ${ }^{67-69}$. In one such study, Arad and colleagues ${ }^{70}$ used a mimetic peptide and produced evidence that divergent SAgs inhibited gene expression of human $\mathrm{T}_{\mathrm{H}} 1$ cytokines. In low molar excess over SAg challenge concentration, this peptide mimetic protected mice from the lethal effects of a broad spectrum of these toxins, even when given post-challenge. The peptide is a mimetic of a domain that is structurally conserved among SAgs, yet it is remote from binding sites for MHC class II and TCR. It has been proposed that SAgs might use this domain to bind to a novel receptor that is crucial for their action (Kaempfer R, personal communication).

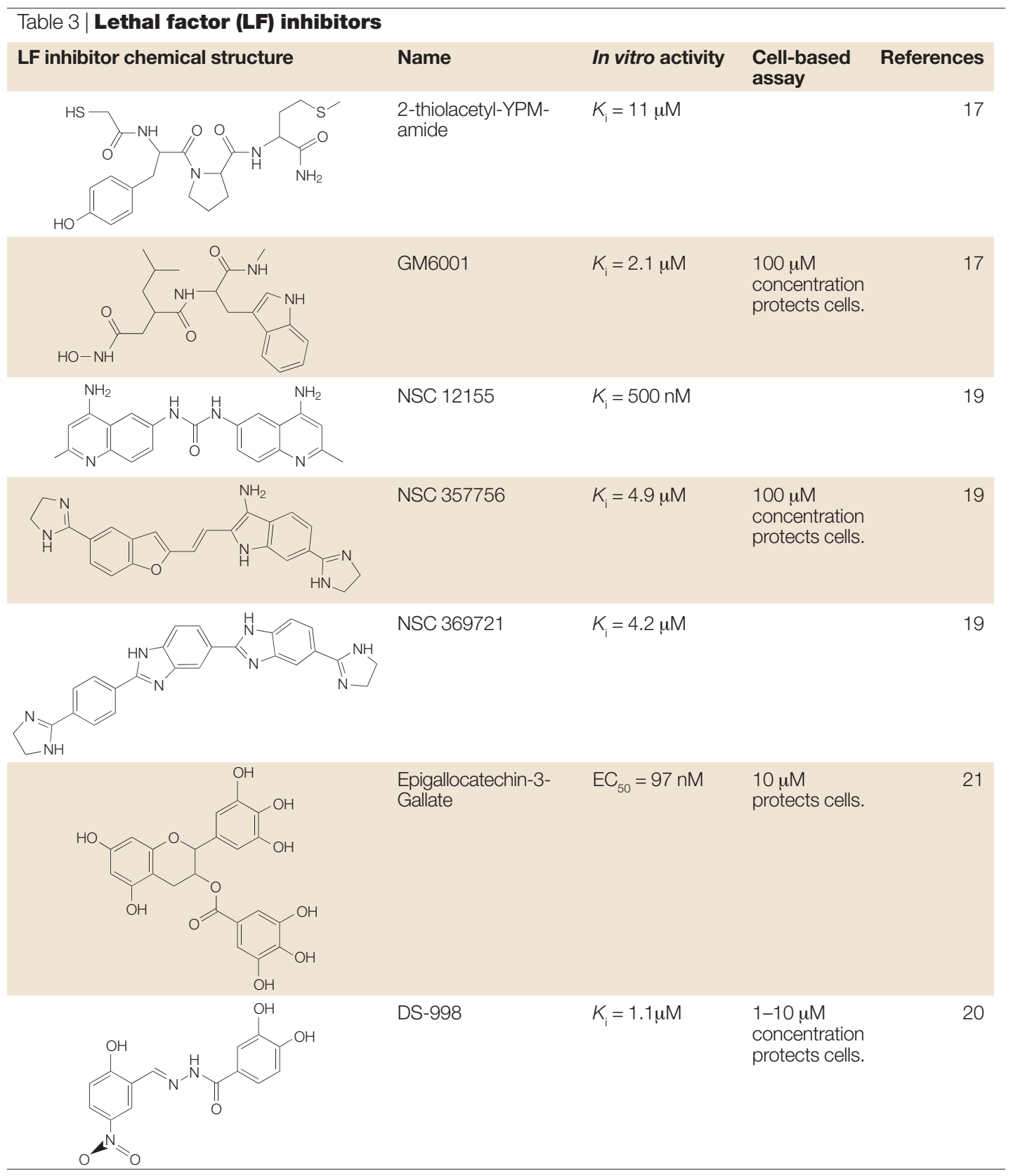



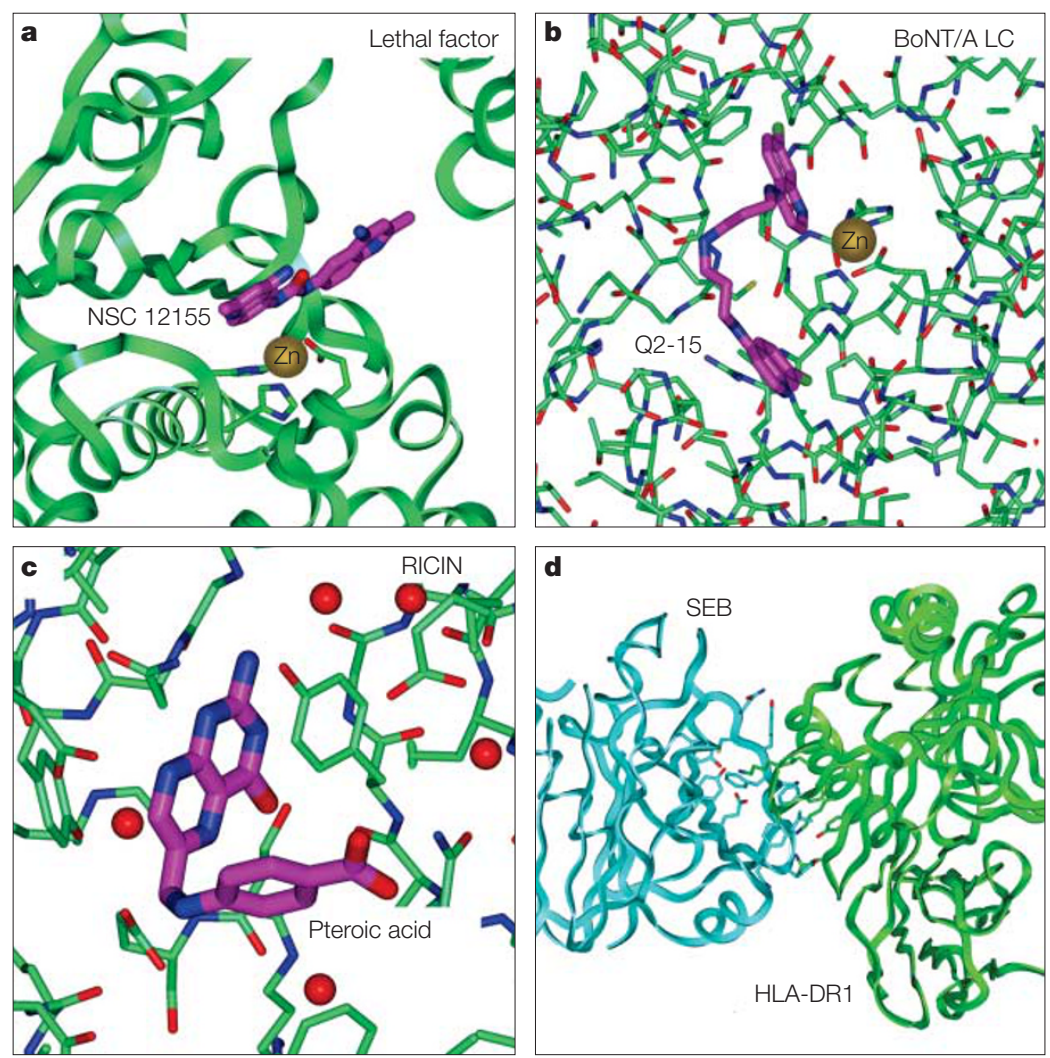

Figure 2 | Toxin interactions with inhibitors (a-c) or other proteins (d). a | The co-crystal structure of NSC 12155 bound in the lethal factor (LF) substrate-binding cleft (PDB Ref Code = 1PWP). LF is shown in green ribbon. Residues of the LF catalytic engine are shown in stick. Carbon atoms are green; oxygen atoms are red; and nitrogen atoms are blue. NSC 12155 carbons are magenta. The inhibitor sits in close proximity to the enzyme's catalytic zinc (gold). b | Inhibitor Q2-15 docked in the botulinum neurotoxin serotype A (BoNT/A) light-chain (LC) substrate-binding cleft. The BoNT/A LC model is a dynamics conformation ${ }^{205}$ generated from the $X$-ray crystal structure of PDB ref code $=1 \mathrm{E} 1 \mathrm{H}$. Colours are as described for $\mathbf{a}$. Additionally, enzyme residues are rendered in stick. Q2-15 carbons are magenta; and Q2-15 chloro substituents are light green. One of the 7-chloro-quinoline components interacts with the catalytic zinc of the enzyme, whereas the other binds in a pocket located behind the catalytic engine of the enzyme. c | The co-crystal structure of pteroic acid bound in the substrate-binding pocket of the ricin A chain (PDB Ref Code = 1BR6). Colours are as described for $\mathbf{a}$ and $\mathbf{b}$. Red spheres are water molecules. $\mathbf{d} \mid$ The co-crystal structure of the SEB-HLA-DR1 interaction (PDB Ref Code $=1$ SEB). $\mathrm{SEB}$ is depicted as cyan ribbons and HLA-DR1 is depicted as green ribbons. The side chains of residues spanning the contact interface are shown in stick, with carbon colours corresponding to protein ribbon colour. Residue oxygens are red and nitrogens are blue.

Targeting viral pathogens: variola and filoviruses Therapeutics for viral infections can be broadly categorized as agents that attack the virus and its replicative cycle directly, or as agents that assist and fortify host immune defences. In principle, there are abundant targets and numerous strategies for both categories. TABLE 8 provides an overview of the strategies and opportunities available for new therapies against a virus, juxtaposed with some of the challenges in bringing such strategies into clinical use. The view presented is necessarily incomplete, but serves to highlight both the apparent vulnerabilities of viruses and the extraordinary challenges inherent to dampening logarithmic viral replication to a medically significant degree. As reviewed recently by De Clercq ${ }^{71}$, there are only 37 licensed antiviral drugs (not including interferons or

antibodies) available for clinical use. Many are for the treatment of HIV, 12 are for treating herpes virus (herpes simplex virus (HSV), Varicella-Zoster virus (VZV) and cytomegalovirus (CMV)) and 4 are for the therapy and prophylaxis of influenza virus. However, a cause for optimism is that the viruses of greatest concern in biowarfare and bioterrorism cause acute viral infections, which for lucky survivors is followed by immune recovery. Antiviral therapies therefore need only be effective for relatively short periods (see BOX 1 for case examples of filoviruses and orthopoxviruses).

Antiviral drugs. Attachment and entry remain enigmas for both filoviruses and orthopoxviruses, and emerging data are mired in uncertainty and controversy. The search for specific filovirus receptors ${ }^{72,73}$ has been countered by evidence of more ubiquitous and unspecific lectin-like receptors ${ }^{74,75}$ that might be difficult to antagonize with drugs. However, recent structure-activity relationship (SAR) studies indicate that Cyanovirin-N, a carbohydrate-binding protein, might inhibit Ebola virus entry ${ }^{76}$. Orthopoxviruses, though very different in their surfaces from the sugary filaments of Ebola and Marburg, are similarly the subject of viral attachment and entry research ${ }^{77}$. Fusion inhibition, which has proven fruitful for treating both HIV and influenza ${ }^{71}$, could provide therapeutic opportunities for both viral genera, and is being actively pursued ${ }^{77-80}$. Inhibition of viral replication seems to be especially feasible for both filoviruses and orthopoxviruses: numerous genomes have been sequenced, several key enzymes identified, basic replicative steps described and structural associations among proteins partially described ${ }^{77,81}$.

This abundance of potential targets could result in several therapeutic approaches, including antisense targeting of the viral genome, inhibition of the replicase or polymerase activity by small-molecule inhibitors, as well as other specific molecular targets essential for the formation of a replication-competent complex $^{82}$. The recent development of reverse genetics and filovirus reporter-based mini-genomes ${ }^{83}$, as well as green fluorescent protein (GFP)-expressing Ebola virus $^{84}$, is expected to significantly facilitate the identification of inhibitors of filovirus replication. Final assembly and viral egress from cells is simpler for filoviruses than for poxviruses. Results from electron microscopy have long indicated that the final assembly of filamentous Ebola and Marburg viruses occurs at cell membranes ${ }^{85,86}$, and recent work has shown that filoviruses are among the subset of viruses that exploit specialized cell-membrane regions called lipid rafts $^{87}$. Filovirus raft assembly might therefore be a viable target. Reverse genetics experiments can be used to explore whether a putative target, such as furin cleavage site of Ebola virus, is essential for viral infection ${ }^{88}$. Compared with filoviruses, poxvirus egress from cells is considerably more complicated ${ }^{77}$, a situation that would seem to make the target even more vulnerable. Over the years, vaccinia virus mutants defective in various aspects of final assembly have been identified, host proteins implicated and 


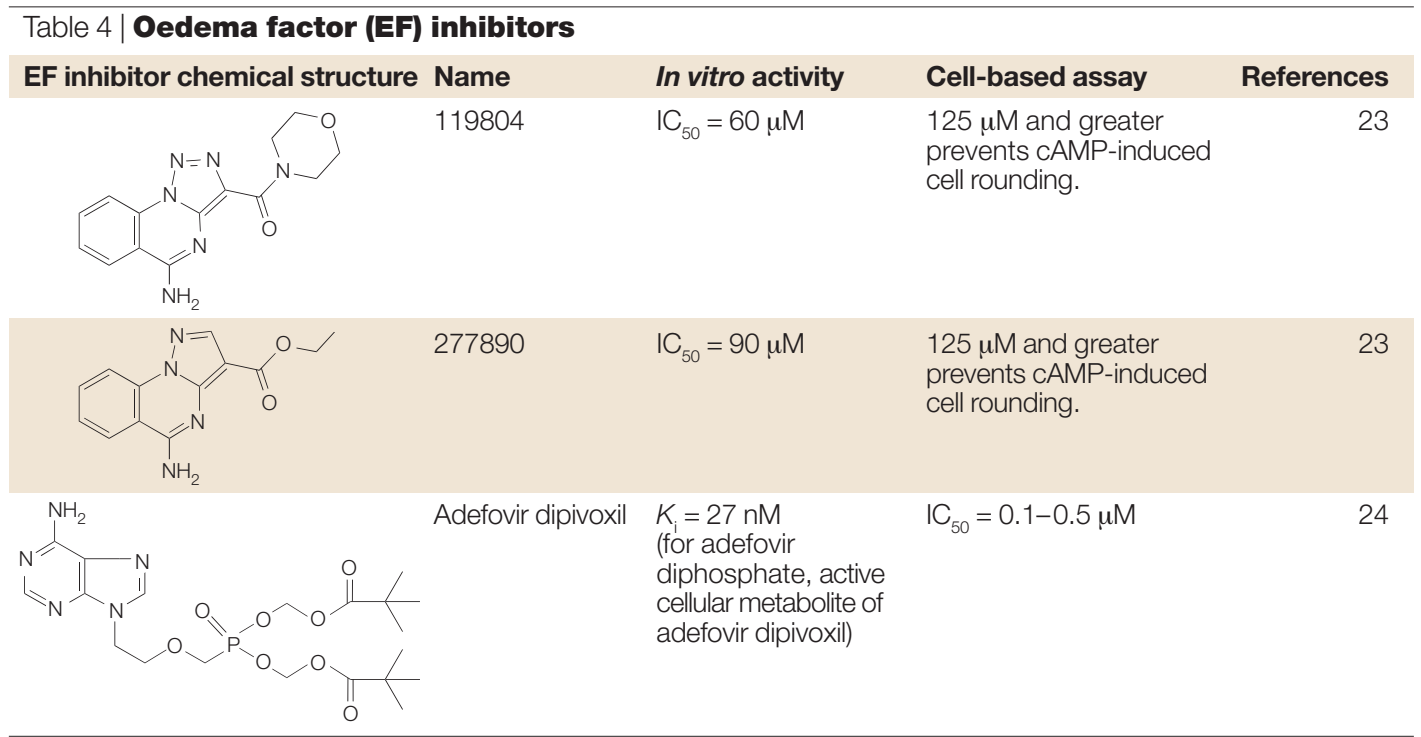

compounds identified that inhibit late particle formation. Additionally, the apparently effective but problematic antiviral drug cidofovir seems to be effective against many orthopoxviruses, and is potentially useful for the treatment of smallpox and vaccinia ${ }^{71,89}$.

Adjunctive therapy. Filovirus infections are associated with a number of pathological conditions, including disseminated intravascular coagulation, which has been proposed to result from upregulation of tissue factor on the surface of leukocytes ${ }^{90}$. Partial success against Ebola virus infections in rhesus monkeys using recombinant nematode anticoagulant protein C2 has recently been reported $^{91}$. Although this study is encouraging, the utility of anticoagulant therapy in humans requires further studies - in particular in combination with specific antiviral therapeutics.

Therapeutic antibodies. Both filoviruses and orthopoxviruses illustrate how the potential complexity and effectiveness of antibody-mediated protection is so often underestimated. Viral neutralization - commonly interpreted to mean the capacity of an immunoglobulin to interfere with viral attachment or entry - is only part of the protective role of antibodies ${ }^{92}$, and is sometimes insufficient.

In rodent models of lethal Ebola and Marburg viruses, the administration of both polyclonal and monoclonal antibodies unambiguously confers protection before and sometimes after viral infection, and the demonstration of virus-neutralizing activity in the transferred antibody is a poor predictor of its efficacy in $v i v o^{93-96}$. The few antibodies tested in sensitive nonhuman primate models of filovirus infection have delayed viraemia and death, but have not been fully preventative when the viral challenge was robust ${ }^{97}$. This has led to premature assertions about the irrelevancy of antibodies as filovirus therapies. Lessons from viral vaccine studies with Ebola and Marburg viruses repeatedly show that antibodies to the viral glycoprotein in conjunction with T-cell responses to this and other proteins are required for optimal protection ${ }^{94,98-102}$. Attempts to influence clinical outcomes in humans by the transfer of plasma from convalescent to ill individuals produced encouraging results ${ }^{103,104}$, but these studies were inadequately controlled and therefore inconclusive.

A common observation in orthopoxviruses is the production of neutralizing antibodies (raised against inactivated virus) that alone prove insufficient to prevent disease and death, but which are protective when combined with an additional antibody population (found in serum from animals that had been infected with live virus) ${ }^{105}$. We repeated this observation both with monoclonal antibodies ${ }^{106}$ and with DNA vaccines that evoked antibodies ${ }^{106,107}$; in this case, even the most potent neutralizing antibodies (against the vaccinia virus protein L1R) were insufficient to prevent the inexorable spread of virus in infected animals. In contrast, an antibody to a virally encoded cell-surface protein (A33R) was sufficient by itself or in conjunction with anti-L1R to provide robust protection from vaccinia virus in rodents. Others, extending the observations to additional proteins, have reported similar findings ${ }^{108}$, and an experimental DNA vaccine against monkeypox virus in non-human primates yielded concordant results ${ }^{107}$. This raises a question: how might antibodies, in addition to neutralizing antibodies, confer a therapeutic effect? Early observations ${ }^{92,109}$ implicated the capacity of antibodies to bind to viral proteins on the surface of infected cells, and subsequent observations, including those with filoviruses and orthopoxviruses, tend to be consistent with the proposed requirement that the targets of non-neutralizing antibodies be externally exposed. Mechanistically, one might evoke complement-mediated lysis of cells, antibody-dependent cellular cytotoxicity (in which Fc receptor-bearing cells destroy virally infected cells), perturbation of late events in viral assembly (as in the drug targeting above) or, as 
in the case of orthopoxviruses, the targeting of a particularly important but quantitatively minor viral population ${ }^{105,108}$. In terms of the therapeutic value of antibodies, complexity is added by the search for antibodies in addition to those that can be assayed rapidly by binding or neutralization. Historically, the potency of vaccinia immune globulin (licensed for the treatment of smallpox vaccine complications) was judged by its neutralization capacity, a strategy salvaged by the acquisition of antibodies from donors whose sera also contained many other antibodies as well ${ }^{110}$.

Augmenting or protecting innate immunity. The goal of some antiviral agents is to tip the balance of the immune response towards innate immunity and allow specific immune clearance mechanisms (adaptive immunity) to take over ${ }^{111}$. At the crossroads of many innate immune responses are interferons, a family of molecules that can directly evoke antiviral responses. However, the utility of interferons as broad-spectrum antivirals has been limited both by the transience and the toxicity of their effects. This has engendered caution about the prospects for a broad array of other newly described cytokines that also stimulate innate immunity. On the other hand, other opportunities for drug intervention have arisen in targeting viral pathogens. The identification of proteins produced by vaccinia and influenza virus that act as interferon antagonists ${ }^{112,113}$ was followed by the demonstration that Ebola ${ }^{114}$ and Marburg ${ }^{115}$ viruses also make interferon antagonists. Additionally, orthopoxviruses synthesize an impressive array of homologues of cytokines, cytokine receptors, complement proteins, growth hormones and other molecules - the effects of which could confound innate immune responses ${ }^{116}$. Our ability to modify the innate immune response in a therapeutically significant manner necessitates a deeper understanding of the role of the components of this arm of the immune system in specific viral infections.
Recently, a crucial role for natural killer (NK) cells was defined in protection against Ebola infection ${ }^{117}$. Interestingly, adoptive transfer of NK cells treated with Ebola virus-like particles and not inactivated Ebola virus resulted in significant protection of mice against lethal challenge, indicating that mobilizing the effector innate response early in infection might be a promising therapeutic strategy against filoviruses.

Targeting host pathways. Viral pathogens have evolved over millennia by adapting to a limited number of cellular mechanisms for cellular entry, replication, assembly and budding. Although a tremendous amount of effort has been devoted in the past decades to the development of therapeutic strategies targeting virus components, half of this work involves a single virus (HIV). In contrast, the common cellular pathways used by a wide array of viruses have been largely neglected as therapeutic targets. In this regard, genetically engineered microbes represent major challenges for biodefence both because the pathogenicity of the organism might be unrecognized and/or the pathogenicity might be tailored to counter existing pathogen-targeted therapeutics. Host-targeted therapeutics would be the most viable option in coping with such unpredictable challenges. Such host-targeted therapeutics would have two advantages: they would act as broad-spectrum therapeutics and block all of the viruses that use the affected pathway; and they would make it more difficult for the pathogen to develop resistance, because there would be few alternative cellular pathways available for the virus to take advantage of. Besides cellular receptors and cofactors, a number of intracellular pathways, such as the vacuolar protein-sorting machinery ${ }^{118}$, cytoskeletal network ${ }^{119}$ and components of cellular antiviral defence $^{120,121}$, have been identified as crucial for viral pathogenesis. However, despite these advances, our understanding of the host pathways involved in viral pathogenesis remains limited. Genetic approaches such

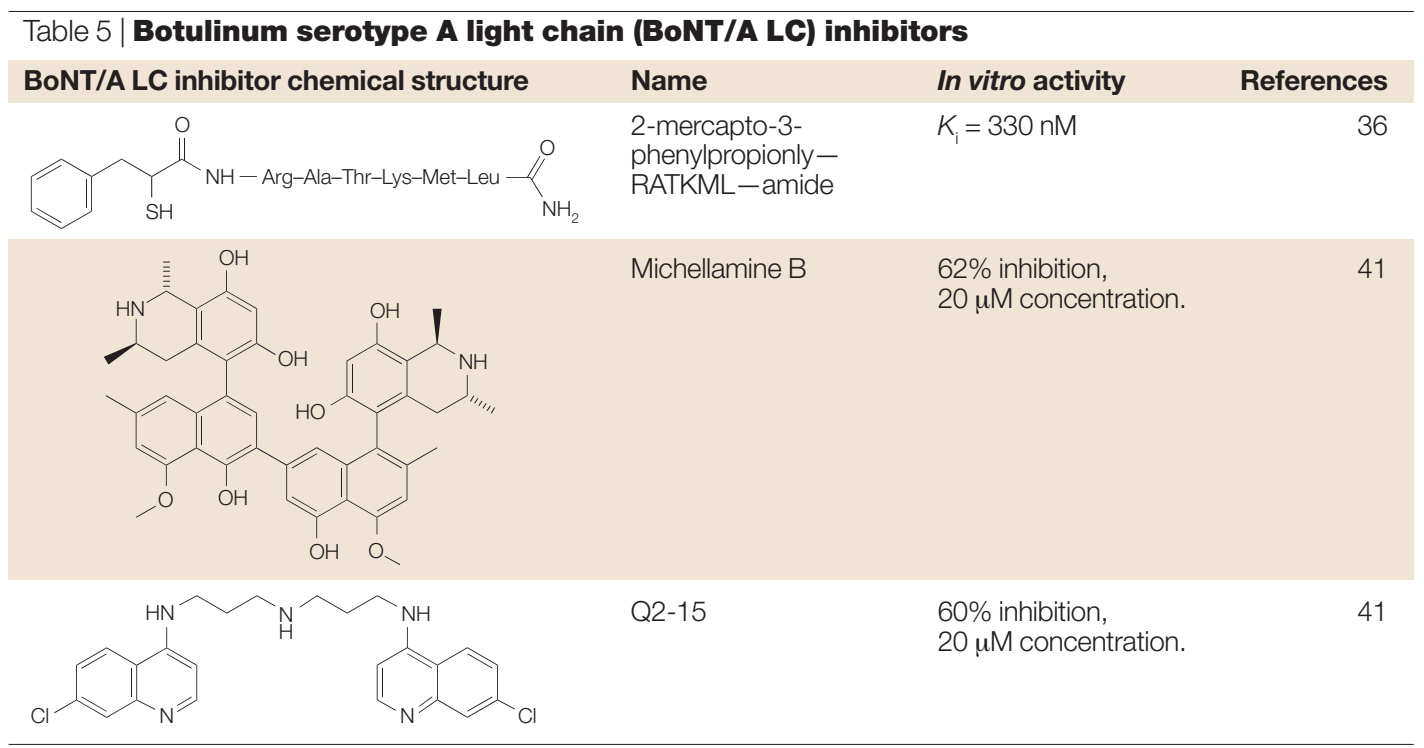




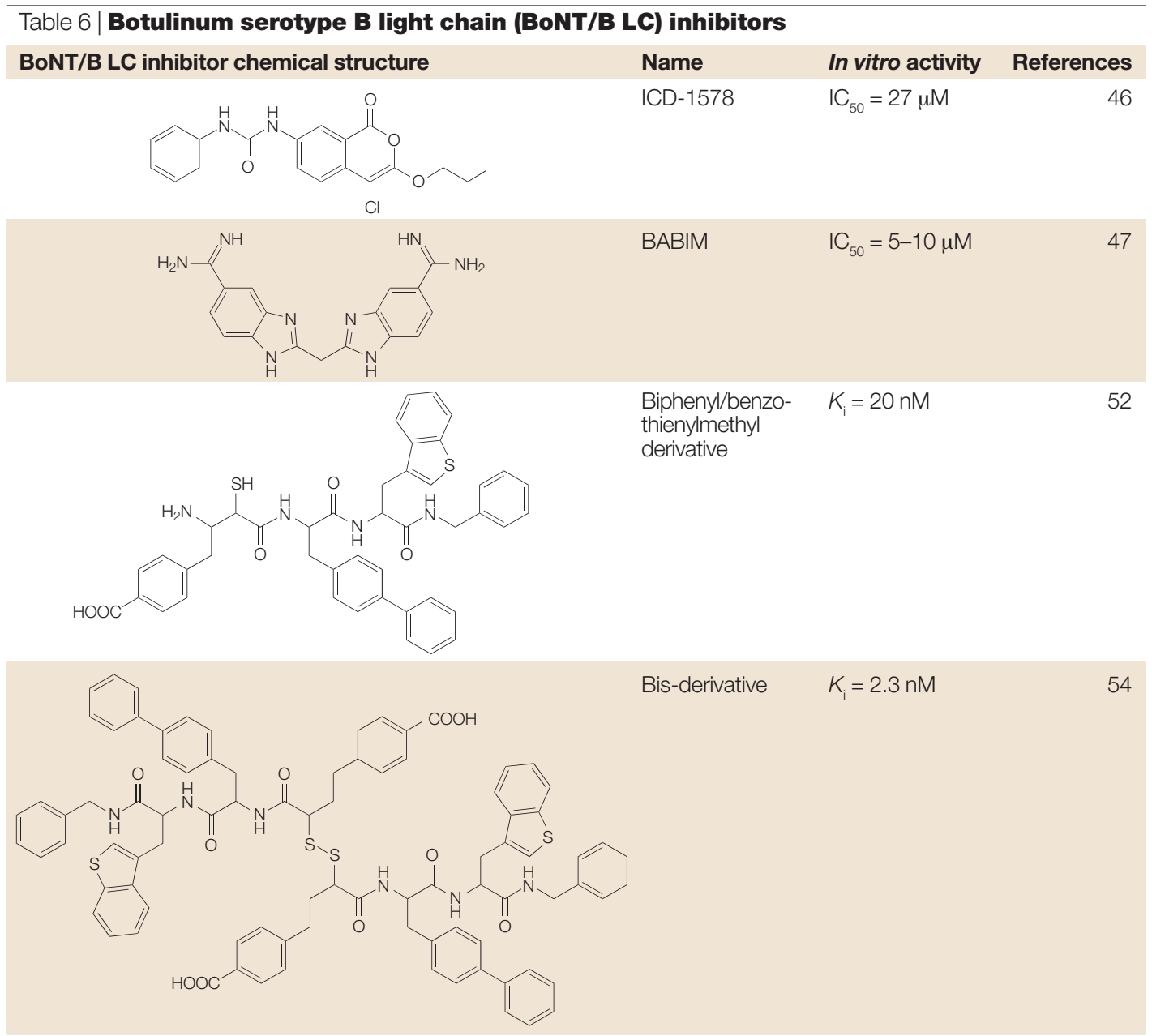

as RNA interference (RNAi), as well as various physical and functional knockout technologies, need to be applied to identify host genetic pathways involved in viral pathogenesis and to establish the degree of commonality of these pathways across viral families. Molecular details of these pathways and the nature of their interactions with viral components need to be intensively studied by genetic, biochemical, structural and modelling approaches. This detailed body of knowledge would serve as a basis for identifying host targets and the rational design of broad-spectrum therapeutic strategies.

\section{Existing antimicrobial treatments}

At this time there are therapeutic protocols for treating those infected with many of the bacterial biowarfare pathogens. However, the scope of recovery is variable in the case of individuals infected with inhalational anthrax, there is a limited window of opportunity during which antibiotics will control and eliminate the infection. This section of the review covers characteristics (TABLE 9) and current drug therapies for three biowarfare agents: anthrax, plague and tularaemia.

Naturally occurring strains of $B$. anthracis are generally susceptible to penicillins, first-generation cephalosporins, tetracyclines, rifampin, aminoglycosides, vancomycin, clindamycin and fluoroquinolones. It was recently found that 20 strains of $B$. anthracis also show sensitivity to imipenem, meropenem, daptomycin, quinupristin-dalfopristin, linezolid, GAR936, BMS284756, ABT773, LY333328 and resistance to clofazamine ${ }^{122,123}$. The CDC and the Working Group for Civilian Biodefense treatment guidelines have been published for treatment of pulmonary anthrax ${ }^{124}$, and are provided in TABLE 10. The choice of the second or third antibiotic should be influenced by the likely resistance pattern of the strain causing the infection, and consideration should be given to antibiotics that penetrate the blood-brain barrier (penicillins and carbapenems, for example) due to the high frequency of meningitis associated with inhalational anthrax exposure $^{125}$. The duration of therapy is controversial, but involves at least 60 days of treatment ${ }^{124,125}$. Corticosteroids have been mentioned as a possible adjunctive therapy in the setting of meningitis or severe mediastinal oedema ${ }^{125}$, but there are no data to definitively support their use.

A major concern with regard to B. anthracis and other microbial biodefence agents is genetically engineered antibiotic resistance. Several reports of recombinant 


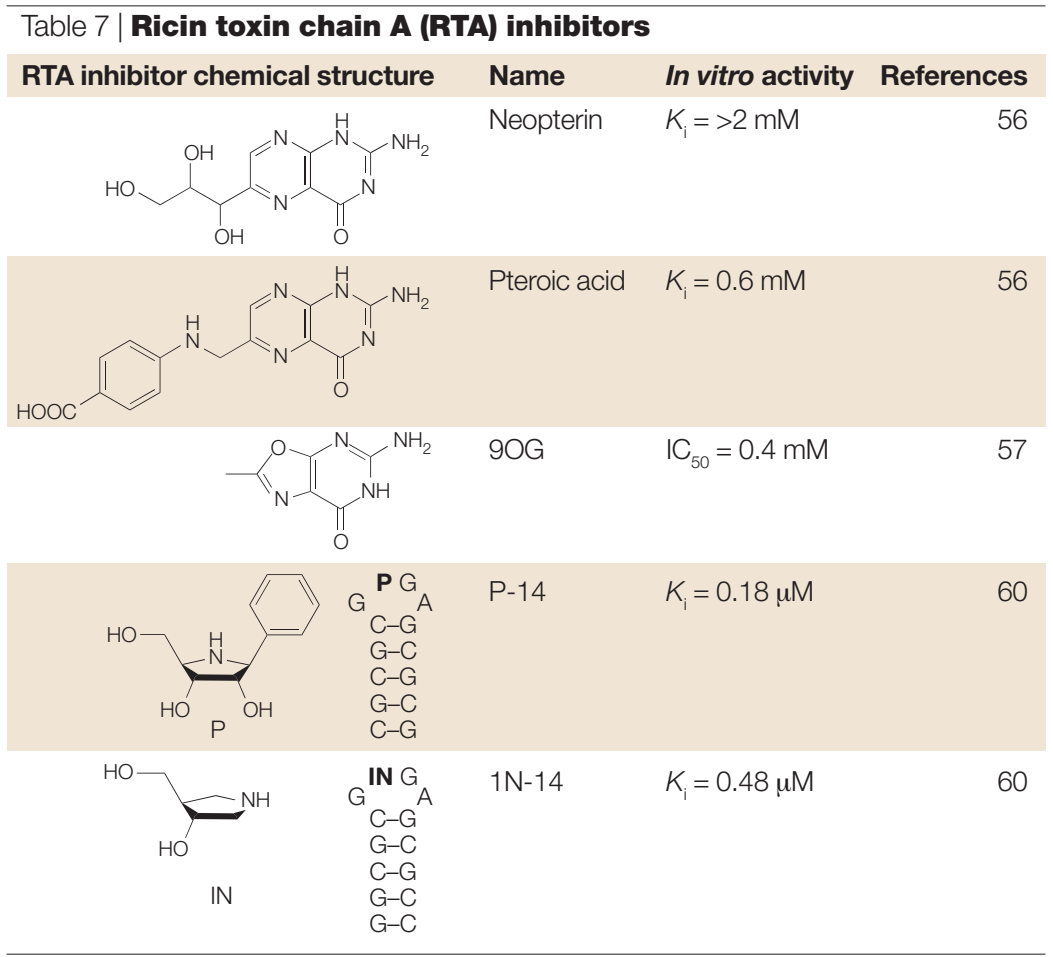

YERSINIA PESTIS

The causative agent of plague, it is an aerobic, Gram-negative bacillus from the bacterial family Enterobacteriaceae. plasmids that confer antibiotic resistance when inserted into B. anthracis have been published. One plasmid-containing strain was resistant to tetracycline, doxycycline and minocycline ${ }^{126}$. In another study, a recombinant plasmid encoding for resistance to penicillin, tetracycline, chloramphenicol, rifampin, macrolides and lincomycin was inserted into the B. anthracis strain STI-1, which reportedly stably inherited the plasmid over several generations ${ }^{127}$. The possibility of antibiotic resistance in this pathogen indicates the

\section{Box 1 | Case examples of filoviruses and orthopoxviruses}

The filoviruses (Ebola and Marburg viruses) and the orthopoxviruses (variola/smallpox, monkeypox and other pox viruses) are high-priority viral threats, and there is an acute need for therapeutics that target these pathogens. Ebola and Marburg viruses are exceptionally deadly (70-90\% mortality in some outbreaks), but are relatively simple viruses, consisting of seven genes encoded in a single strand of $\mathrm{RNA}^{159}$. They are moderately contagious, but otherwise have numerous characteristics commonly associated with biological weapons $\mathbf{s}^{160}$. These viruses are endemic in Africa ${ }^{161,162}$ and, despite a great deal of scientific progress in the past 10 years $^{81,93,95,96,98,163-165}$, no vaccines or treatments are available for clinical use. For comparison, orthopoxviruses are large DNA viruses that have nearly 200 genes and some of the most complex viral replication cycles known. Variola virus, which causes smallpox, is the most feared of this genus ${ }^{166}$ because it is highly contagious, incapacitating, disfiguring and potentially deadly (historical highs of around $40 \%$ mortality in unvaccinated persons). Monkeypox, a rodent virus endemic in Africa, is far less contagious than variola but in some outbreaks has caused up to $10 \%$ mortality in unvaccinated individuals. The classical smallpox vaccine, which consists of vaccinia virus, affords relatively robust protection against both variola and monkeypox viruses, but has proven problematic in the modern era not only because of previously known adverse reactions (including disseminated vaccinia), but because of a rediscovered association with myocarditis ${ }^{167,168}$. However, safer vaccines are in the research pipeline ${ }^{107,169}$. Vaccinia immune globulin, an antibody-containing product from vaccinated persons, was licensed and is now offered under investigational status for the treatment of disseminated vaccinia ${ }^{89}$.

importance of initial combination therapy when exposure to a genetically modified strain is suspected.

YERSINIA PESTIS is typically susceptible in vitro to penicillins, many cephalosporins, imipenem, meropenem, aminoglycosides, amikacin, quinolones and tetracyclines. It is variably susceptible to trimethoprim, chloramphenicol and rifampin, and is commonly resistant to macrolides, clindamycin, novobiocin, quinupristindalfopristin and clofazamine (H. Heine, personal communication). (See TABLE 10 for recommended antibiotic treatments for pneumonic plague.) The preferred therapy for $Y$. pestis infection is an aminoglycoside, with streptomycin as an FDA-approved medication and gentamicin often mentioned as an alternate antibiotic.

Although rarely reported, naturally occurring, highly antibiotic-resistant strains of $Y$. pestis do occur. In a recent report, a strain isolated from a boy in Madagascar was demonstrated to have acquired a plasmid that mediated resistance not only to streptomycin, chloramphenicol and tetracycline, but also to ampicillin, sulphonamides, kanamycin, spectinomycin and minocycline. These naturally occurring, highly resistant antibiotic strains are extremely concerning with respect to the development of biological weapons.

FRANCESELLA TULARENSIS is generally susceptible in vitro to aminoglycosides, tetracyclines, rifampin and chloramphenicol ${ }^{128-133}$; however, many strains seem to be resistant to $\beta$-lactam and monobactam antibiotics ${ }^{133}$. (See TABLE 10 for recommended tularaemia treatments.) Similarly to the treatment of plague, streptomycin or gentamicin are the preferred therapy when there are no contraindications to the use of these medications ${ }^{134,135}$. Ciprofloxacin was effective in treating a recent tularaemia outbreak in Spain ${ }^{136}$.

\section{Rapid detection and diagnostics}

The early detection and diagnosis of infection or intoxication with biological select agent and toxin (BSAT) is essential if intervention is to occur at a point at which the prognosis can still be influenced, and also to guide the selection of the optimum therapeutic protocol (TABLE 10). In addition, such information can greatly facilitate the logistics of mobilizing supplies and personnel to areas of exposure. Here, 'detection' is defined as including those technologies required to identify a biological threat in the environment before or coincident with exposure. Environmental detection usually involves the testing of air, soil, fomites, water and foodstuffs. 'Laboratory diagnosis' includes those methods used to confirm the clinical observations of a physician by evaluation of standard clinical specimens, such as blood, serum, exudates, saliva, stool and tissues (TABLE 9). The necessity for the rapid detection of BSAT-related illness and intervention with optimal therapeutic protocols was well illustrated during the 2001 anthrax attacks (BOX 2).

Challenges facing the National Laboratory Response Network. In 1999 a national laboratory response network (LRN) for bioterrorism was established by the $\mathrm{CDC}$ to test for biological and chemical agents (see FIG. 3 


\section{Table 8 | Quenching viral replication: opportunities and challenges}

\section{Viral event}

Virus (free or extracellular)

\section{Attachment to cells}

Binding of virus to receptor(s) or unspecific ligands. Earliest signalling of innate immunity.

Gradual inactivation in a cell-free environment. or DNA, sometimes stepwise or

\section{Dynamic consequences}

Penetration and unveiling of RNA compartmentalized. Early defence cascades activated, including interferons, RNAi, apoptosis.

\section{Complex cycle of transcription, translation and genome replication \\ Cell defence cascades are amplified; viral antagonists of intra- and extracellular defences produced; viral proteins on cell surfaces expressed; viral proteins secreted; MHC- associated viral peptides processed; perturb 'normal' cell surface. \\ Specific or quasi-specific \\ Pre-assembly: an orchestrated, compartmentalized associations between viral proteins and nucleic acids.} encapsidation of nucleic acid with viral proteins

Final assembly: can involve translocation, acquisition of outer capsid and/or budding from cell membranes

Repitition in vivo, manifested by tissue tropisms, damage and disease

Self-assembly driven by specific binding and movement of proteins; preferential assembly in specialized proteins (for example, lipid rafts); exploitation of cellular proteins and pathways (for example, TSG101); cell exhaustion and apoptosis; and death.

\section{Logarithmic amplification of} viral burden; fatal virus- induced lesions in crucial organs; triggering of 'cytokine storms';

\section{Opportunities}

Specific binding and harmless removal of virus - for example by antibodies, heteropolymers and small molecules. Specific binding by drug or antibody to destabilize or irreversibly stabilize coat.

Receptor blockade by antibodies or other drugs. Deliberate prior activation of innate immunity.

Binding to fusion domain, fusion inhibition. Targeting exposed RNA, DNA, for example, nuclease, antisense.

Specifically bind/disrupt viral protein/nucleicacid functions and interactions (for example, protease inhibitors and replicase inhibitors); competitively inhibit viral antagonists of innate and adaptive immunity; specifically target viral proteins on cell surfaces (for example, antibodies for ADCC or targeted toxin); exploit, amplify and influence the innate and adaptive responses (for example, NK cells and CTL) to eliminate 'modified self'.

Identify and inhibit protein-protein interactions; perturb nucleic-acid encapsidation motifs (for example, using a drug antagonist or antisense). immunopathology from potent but lagging response.
Bind and disrupt proteins involved in final packaging; reversibly perturb essential cellular sites and proteins.
Treat symptoms to sustain victim until immune system prevails; manage immune response and cytokine polarity.

\section{Challenges}

Phenotypic variation of viral population (quasi-species). Possibility of enhancing uptake and therefore disease. Natural diversity of coats among viral species and strains.

Genotypic and phenotypic variation present in an amplifying virus population and escape mutants. Redundancy and degeneracy in viral and cell receptors. Adverse and transient effects of activating innate immunity.

Fusion domains often cryptic, and are only transiently accessible. Nucleic acids protected by viral proteins, compartmentalization.

Delivery of active compounds to intracellular targets; identification of appropriate targets; escape mutants, variation among viral strains; insufficient knowledge of how to safely manipulate the immune system without exacerbation of disease and autoimmunity in some individuals.

Delivery of active compounds to intracellular targets; identification of appropriate targets.

Delivery of active compounds to intracellular targets; identification of appropriate targets; overall safety of compounds that disrupt cellular processes.
Discovery of active compounds; addressing issues of drug or antibody pharmacokinetics, bioavailability, efficacy, feasibility and safety.
FRANCESELLA TULARENSIS

The causative agent of tularaemia, it is a small, aerobic Gram-negative coccobacilli. This agent is the most infectious human pathogen known. In the past, both the former Soviet Union and the US had programmes to develop weapons containing this bacterium. for a schematic of the process) that could be used during a terrorism incident ${ }^{137,138}$. Each laboratory in the LRN follows the same rules for sample collection, shipping, agent containment and testing. LRN laboratories maintain secure communication channels among themselves, state and local health authorities, CDC and other federal agencies. The mission of the LRN is to maintain a laboratory network that will quickly respond to acts of biological and chemical terrorism. The system is now organized into a collection of surveillance (previously known as level A), confirmatory (level B and C) and national laboratories (level D).

FDA-approved assays do not exist for most BSAT. The CDC therefore provides LRN-registered clinical laboratories, which are the front-line laboratory responders to biological terrorism, with approved protocols for most of the category A agents and some category B agents. LRN protocols use an integrated system of well-established microbiological methods, PCR gene amplification and improved immunodiagnostic assays ${ }^{139}$. CDC-supplied reagents and standards exist for the identification of B. anthracis, BoNT/A, $Y$. pestis, F. tularensis and Brucella spp. For a large number of agents, specimens must be sent directly to the CDC in Atlanta, Georgia, USA, or to designated LRN reference laboratories because of the extreme hazard they represent to clinical laboratory personnel and the technical complexity of the analysis required. In most cases the LRN system requires a combination of a screening evaluation at the level of the local hospital clinical laboratory and confirmation by a hierarchical reference laboratory in the system. TABLE 10 shows the estimated time required for conducting LRN protocols, assuming a low-complexity sample or specimen. We can expect that the time required for laboratory confirmation will be worse for samples that must be transported to the 


\begin{tabular}{|c|c|c|c|}
\hline BSAT & Biological characteristics & Clinical specimens & Diagnostic methods \\
\hline Anthrax & $\begin{array}{l}\text { Gram-positive rod; spore-forming; } \\
\text { aerobic; non-motile; catalase positive; } \\
\text { large, grey-white to white, non-haemolytic } \\
\text { colonies on sheep-blood agar plates. }\end{array}$ & $\begin{array}{l}\text { Blood; cerebral spinal fluid; } \\
\text { pleural effusion fluid; } \\
\text { skin-lesion material such } \\
\text { as vesicular fluid or eschar. }\end{array}$ & $\begin{array}{l}\text { Culture; } \gamma \text {-phage } \\
\text { sensitivity; } \\
\text { immunohistochemistry; } \\
\text { PCR. }\end{array}$ \\
\hline Botulism & $\begin{array}{l}\text { Gram-positive rod; spore-forming; obligate } \\
\text { Anaerobe; catalase negative; lipase } \\
\text { production on egg yolk agar; } 150-k D a \\
\text { protein toxin (types A-G); } 2 \text { subunits. }\end{array}$ & $\begin{array}{l}\text { Serum; gastric aspirates; stool; } \\
\text { respiratory secretions. }\end{array}$ & $\begin{array}{l}\text { Culture; immunoassay; } \\
\text { mouse neutralization } \\
\text { assay; PCR. }\end{array}$ \\
\hline Plague & $\begin{array}{l}\text { Gram-negative coccobacilli often } \\
\text { pleomorphic; non-spore forming; facultative } \\
\text { anaerobe; non-motile; beaten copper } \\
\text { colonies (MacConkey'sagar). }\end{array}$ & $\begin{array}{l}\text { Lymph node smears; } \\
\text { aspirates; sputum; blood; } \\
\text { cerebral spinal fluid. }\end{array}$ & $\begin{array}{l}\text { Culture; } \\
\text { immunofluorescence } \\
\text { assay; PCR. }\end{array}$ \\
\hline Smallpox & $\begin{array}{l}\text { Large double-stranded DNA virus; enveloped, } \\
\text { brick-shaped morphology; Guarnieri bodies } \\
\text { (virus inclusions) under light microscopy. }\end{array}$ & $\begin{array}{l}\text { Throat swabs; induced } \\
\text { respiratory secretions; serum; } \\
\text { aspirates; tissue scrapings. }\end{array}$ & $\begin{array}{l}\text { Viral culture; PCR; EM; } \\
\text { immunohistochemistry; } \\
\text { immunoassay. }\end{array}$ \\
\hline Tularaemia & $\begin{array}{l}\text { Extremely small, pleomorphic, Gram-negative } \\
\text { Coccobacilli; non-spore forming; facultative } \\
\text { intracellular parasite; non-motile; catalase } \\
\text { positive; opalescent smooth colonies on } \\
\text { cysteine heart agar. }\end{array}$ & $\begin{array}{l}\text { Blood culture; serum; ulcer } \\
\text { material; conjunctival } \\
\text { exudates; sputum; gastric } \\
\text { washes; pharyngeal exudates. }\end{array}$ & $\begin{array}{l}\text { Culture; PCR; } \\
\text { immunoassay. }\end{array}$ \\
\hline $\begin{array}{l}\text { Ebola and } \\
\text { Marburg }\end{array}$ & $\begin{array}{l}\text { Linear, negative-sense single-stranded RNA } \\
\text { virus; enveloped; filamentous or pleomorphic, } \\
\text { with extensive branching, or U-shaped, } \\
6 \text {-shaped or circular forms; limited cytopathic } \\
\text { effect in Vero cells. }\end{array}$ & $\begin{array}{l}\text { Serum; liver; spleen; lymph } \\
\text { nodes; kidney; lung; and } \\
\text { gonads. }\end{array}$ & $\begin{array}{l}\text { Viral culture; PCR; EM; } \\
\text { immunoassay; } \\
\text { immunohistochemistry. }\end{array}$ \\
\hline $\begin{array}{l}\text { Viral } \\
\text { encephalitides }\end{array}$ & $\begin{array}{l}\text { Linear positive-sense single stranded } \\
\text { RNA virus; enveloped, spherical virions } \\
\text { with distinct glycoprotein spikes; cytopathic } \\
\text { effect in Vero cells. }\end{array}$ & $\begin{array}{l}\text { Throat swabs; serum; } \\
\text { cerebrospinal fluid. }\end{array}$ & $\begin{array}{l}\text { Viral culture; PCR; EM; } \\
\text { immunoassay; } \\
\text { immunohistochemistry. }\end{array}$ \\
\hline Ricin toxin & $\begin{array}{l}60-65 \text { kDa-protein toxin; two subunits; } \\
\text { castor bean origin. }\end{array}$ & $\begin{array}{l}\text { Serum; stool; urine; spleen, } \\
\text { lung, kidney. }\end{array}$ & Immunoassay. \\
\hline
\end{tabular}

*Includes screening methods and confirmatory assays supplementing standardized protocols in the US National Laboratory Response Network. BSAT, Biological Select Agent and Toxin.

centrally responding CDC laboratory after screening at the local level, as required for smallpox and haemorrhagic fevers. On the basis of the limited public reports of the 2001 response to anthrax attacks, the calculated median time from first medical visit to laboratory confirmation for suspected cutaneous and inhalation anthrax cases $(n=22)$ was 9 days $^{140,141}$. In most of the cases, in which an optimal antibiotic set was initiated as the first therapeutic option, the diagnosis depended on the astute observations and the sensitivity of the attending physician to the possibility of anthrax. Although the laboratory response has technically improved since 2001, the reaction to an unknown or a genetically engineered threat could mimic the 2001 experience.

Watching and sensing for biothreat agents. Two federally sponsored programs, BioWatch and BioSense, are in the early stages of implementation and will encourage the recognition of biological threat attacks on a wide scale ${ }^{142,143}$. The BioWatch Program, which is a collaborative program between the Environmental Protection Agency (EPA), the Department of Homeland Security (DHS), the CDC and local authorities, will provide round-the-clock environmental monitoring for the intentional airborne release of select biological threats. Solid-phase filters and sometimes aqueous concentrates from BioWatch air samplers are evaluated for the presence of pathogens by designated local or state public-health laboratories using LRN protocols and assays. Similar surveillance systems are planned for post offices, and research has begun to devise systems to protect buildings using 'smart' monitoring systems ${ }^{144,145}$. Presumably after confirmation of the intentional release of a biological agent, local officials will implement a response plan that might include widespread prophylaxis and treatment in accordance with the public-health threat. The BioSense Program will use epidemiological methods to monitor selected surrogate markers of infectious disease outbreaks, such as emergency room visits, absentee rates at schools and work, pharmacy visits and other indicators. Possible limitations for both BioWatch and Biosense are described in BOX 3.

Traditional immunodetection. The detection of agentspecific antibodies has been a traditional method to confirm clinical diagnoses. Others have demonstrated assays for the rapid detection of anthrax-specific antibodies in patient sera ${ }^{146}$. Recently, the FDA approved the use of the first commercial assay that detected anthrax-specific antibodies with high sensitivity and specificity. Although these assays are sensitive for detecting anthrax-specific antibodies in highly immunized individuals and convalescent sera, they might not be effective for identifying patients in the early stages of disease. Among postal workers, who arguably received 


\begin{tabular}{|c|c|c|c|c|c|c|}
\hline BSAT & $\begin{array}{l}\text { CDC } \\
\text { category }\end{array}$ & $\begin{array}{l}\text { Incubation } \\
\text { period }^{*}\end{array}$ & $\begin{array}{l}\text { Disease } \\
\text { duration* }\end{array}$ & $\begin{array}{l}\text { Diagnostic } \\
\text { approaches }^{\ddagger}\end{array}$ & $\begin{array}{l}\text { Time to } \\
\text { diagnosis }^{\ddagger}\end{array}$ & $\begin{array}{l}\text { Therapeutic } \\
\text { options }\end{array}$ \\
\hline Anthrax & A & 1-6 days & $\begin{array}{l}\text { Death in } 3-5 \\
\text { days (untreated) }\end{array}$ & Level A Protocol & $18-24 \mathrm{~h}$ & $\begin{array}{l}\text { Ciprofloxicin, } \\
\text { doxycycline, penicillin }\end{array}$ \\
\hline Botulism & A & $1-5$ days & $\begin{array}{l}\text { Death in 24- } \\
72 \mathrm{~h} \text { (untreated); } \\
30-60 \text { days } \\
\text { w/treatment }\end{array}$ & Level A Protocol & 3-21 days & $\begin{array}{l}\text { Equine \& human } \\
\text { antitoxin }\end{array}$ \\
\hline Plague & A & 2-3 days & $\begin{array}{l}1-6 \text { days } \\
\text { (usually fatal) }\end{array}$ & Level A Protocol & 2 days & $\begin{array}{l}\text { Tetracycline, } \\
\text { doxycycline }\end{array}$ \\
\hline Smallpox & A & $7-17$ days & 4 weeks & Level D Protocol & $24-48 h$ & $\begin{array}{l}\text { Vaccinia vaccine, } \\
\text { cidofovir }\end{array}$ \\
\hline Tularaemia & $A$ & $1-21$ days & $>2$ weeks & Level A Protocol & 3 days & $\begin{array}{l}\text { Streptomycin, } \\
\text { gentamicin }\end{array}$ \\
\hline Ebola & A & 4-21 days & $\begin{array}{l}7-16 \text { days } \\
\text { (usually fatal) }\end{array}$ & Level D Protocol & 1-3 days & Supportive care \\
\hline Marburg & $A$ & 9-10 days & $\begin{array}{l}5-14 \text { days } \\
\text { (usually fatal) }\end{array}$ & Level D Protocol & $1-3$ days & Supportive care \\
\hline Brucellosis & $B$ & 5-60 days & $\begin{array}{l}>8 \text { weeks to } \\
>1 \text { year }\end{array}$ & Level A Protocol & 14-21 days & $\begin{array}{l}\text { Doxycycline and } \\
\text { rifampin }\end{array}$ \\
\hline Glanders & $\mathrm{B}$ & 10-14 days & $7-10$ days & Classical Protocol & 1-3 days & $\begin{array}{l}\text { Sulphadiazine, tetra- } \\
\text { cyclines, ciprofloxacin, } \\
\text { streptomycin, novo } \\
\text { biocin, gentamicin, } \\
\text { imipenem, ceftrazidime }\end{array}$ \\
\hline Q Fever & B & $10-40$ days & 2-14 days & Classical Protocol & $7-14$ days & $\begin{array}{l}\text { Tetracycline, } \\
\text { doxycycline }\end{array}$ \\
\hline $\begin{array}{l}\text { Viral } \\
\text { encephalitides }\end{array}$ & $B$ & 2-6 days & 2-21 days & Level D Protocol & 1-3 days & Supportive care \\
\hline Ricin toxin & B & $18-24 \mathrm{hr}$ & $1-12$ days & Level D Protocol & $1-5$ days & Supportive care \\
\hline
\end{tabular}

${ }^{*}$ Adapted from REF. 137. FFrom the Emergency Preparedness and Response website of the Centers for Disease Control and Prevention (htpp://www.bt.cdc.gov). Surveillance laboratories (level A); national laboratories (level D)

the highest dose of anthrax spores during the 2001 anthrax attacks, the mean duration between exposure and onset of disease was 4.5 days. Disease onset in these cases would be prior to the development of a robust humoral antibody response. Moreover, the need to collect paired acute and convalescent sera could limit the usefulness of these assays as epidemiological tools.

Bioagent-directed detection. Promising new technologies could enable the early recognition of replicating aetiological agents and their virulence factors. Potentially, the amplification of variable gene regions flanked by conserved sequences, followed by electrospray ionization mass spectrometry and base-composition

\section{Box 2 | The necessity for BSAT rapid detection}

During the 2001 anthrax attacks, although several patients had exposure to anthrax spores confirmed by nasal swab culture, no cases of disease occurred in the $\sim 32,000$ Senate staff and postal workers immediately targeted for postexposure chemoprophylaxis ${ }^{140,170}$. By contrast, the postsyndromic group of inhalation anthrax-infected patients had a case mortality rate of approximately $45 \%{ }^{141}$. These data were consistent with other studies that suggested that early and aggressive treatment is necessary to influence survival after exposure to inhalation anthrax ${ }^{171,172}$. analysis of the products could be one approach. This approach, called triangulation identification for genetic evaluation of risks (TIGER) ${ }^{147}$, provides a high-throughput, multiple detection and identification system for nearly all known, newly emergent and bioengineered agents in a single test. This rapid, robust and culture-free system has been used to identify agents such as severe acute respiratory syndrome (SARS)-related coronavirus before their recognition by traditional methods. Robust and portable systems have been proposed for the development of civilian and military applications.

Biosensing represents another evolving mechanism for early detection. Here, single proteinaceous nanometer-scale pores (such as anthrax PA) can be easily applied to provide the physical basis for rapid biosensing applications. The mechanism of nanopore-based detection is simple: analytes that either bind to the nanopore or thread through it alter the ionic current in a characteristic manner. For example, the reversible binding of hydronium and deuterium ions to the $\alpha$-hemolysin ion channel causes current fluctuations with amplitude and spectral signatures that indicate the type and concentration of the isotope that is present ${ }^{148}$. The same ion channel was also used to detect and characterize individual molecules of single-stranded DNA that are driven electrophoretically through the pore ${ }^{149}$. This latter technology was used to detect other analytes in solution. 


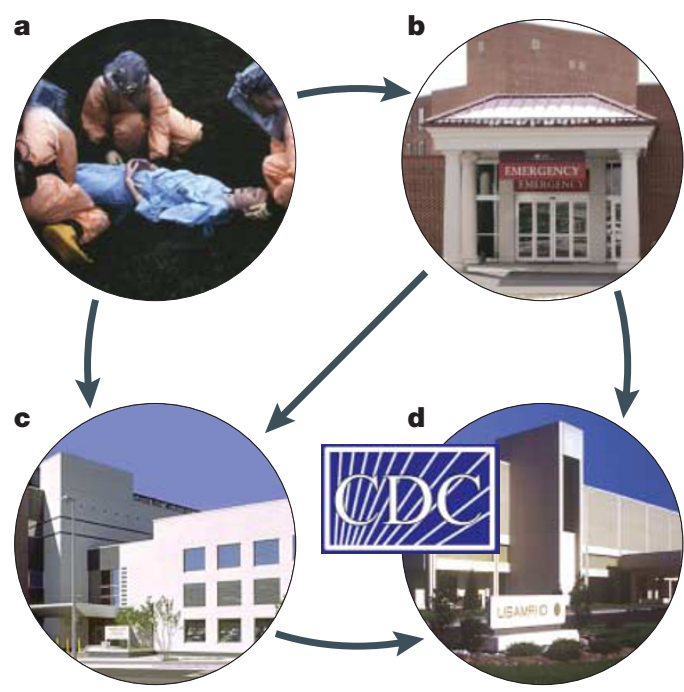

Figure 3 | A schematic of how components of the national laboratory response network (LRN) coordinate when detecting and diagnosing a biothreat agent. a | Initial responders collect evidence, which is then sent to surveillance laboratories or to confirmatory laboratories directly $(\mathbf{b}, \mathbf{c})$. Cooperation between these laboratories facilitates first line response procedures. d | Further confirmation of agent type and area of distribution, is then conducted at national laboratories.

Specifically, analytes of interest that bind to sites on pore-permeant polynucleotides alter the ability of the DNA to enter and thread through the pore ${ }^{150}$. These approaches can be extended into biosensing of anthrax toxin at pM amounts (J. Kasianowicz and K. Halverson, personal communication).

\section{Box 3 | BioWatch and Biosense limitations}

Although the BioWatch and BioSense Programs represent significant improvements in biological defence readiness, they could, however, fail to influence morbidity and mortality in the case of an attack. BioWatch will probably document an attack when a biological threat agent is used on the scale of a weapon of mass destruction. However, extensive epidemiological surveillance might still be necessary before wide-scale prophylaxis is implemented. Another issue that is yet to be resolved is whether environmental sampling is sufficient to trigger a wide-scale medical response. The FDA might have to review environmental detection technologies if they influence medical decision-making. A measured and conservative approach is likely. During the 2001 anthrax attacks, Senate workers were screened and successfully treated after initial environmental test results were confirmed. But treatment of other populations might have been delayed by confusion and the lack of reliable laboratory confirmation $^{145}$. BioWatch samplers might not be effective for limited attacks on individuals or contamination of water and food sources. In the case of BioSense, surrogate markers of infectious disease outbreaks can only be lagging indicators of an attack. There could be hundreds or thousands of cases before an outbreak is recognized, depending on the sensitivity of the final system. Smallpox virus has a comparatively long incubation time of up to 17 days (TABLE 10). By the time BioSense detects a smallpox attack, multiple foci of infection across the country, with coincident close contact spread, would most likely already be developing using current disease models ${ }^{173,174}$
Host-directed detection. A powerful approach for identifying exposed or infected individuals is to develop highly specific and extremely sensitive innate biomarkers that can be detected very early after exposure to a biological agent. There are a number of different types of biomarkers, but one of the most effective methods for identifying highly specific and acutely sensitive biomarkers is through the use of gene- and protein-expression-profiling technologies ${ }^{151-153}$. The advantage of geneexpression studies is that they are large-scale (able to monitor gene-expression changes across an entire genome in one assay), high throughput and highly cost effective (relative to other methods). For example, one of the areas in which this technology has received the greatest attention is in identifying biomarkers for cancer, a field in which expression profiling has been accepted as a powerful tool for identifying specific biomarkers for disease progression, and discriminating between different subtypes of cancer, and, in some cases, identifying biomarkers for susceptibility to specific therapeutics ${ }^{154-156}$.

With regard to infectious diseases, expression profiling of human neutrophils exposed to bacteria reveals dramatic changes in the level of hundreds of mRNA species, including those for cytokines, receptors, membrane-trafficking regulators and genes involved in apoptosis $^{155}$. More importantly, expression profiling of the neutrophil response indicates that key differences in mRNA-expression patterns could be detected on the basis of whether the cells were exposed to pathogenic or non-pathogenic bacteria. Other studies of virus-host interactions using expression technologies and genomic systems studies of host-pathogen interactions have identified specific host factors that pathogens can subvert to optimize their replication and life cycle ${ }^{154,156}$.

Recently, gene-expression-profiling technologies have been applied to the identification of biomarkers for predicting the toxicity of compounds. The field of toxicogenomics has received much interest in both the commercial and academic sectors because of its capability to successfully predict the toxicity of compounds in drug development research, as well as in environmental studies ${ }^{157}$. Existing expertise could be harnessed and applied to developing predictive models to assess the extent of exposure to a biological agent, disease progression and to predict clinical outcomes.

In the future, the creation of a widely available human-gene-expression database of responses to biological threat agents would be extremely beneficial for the rapid and decisive identification of each agent — via a quick and simple blood test. Traditional methods for the identification of biological agents have focused on identifying the agent itself rather than identifying host response. However, many biological agents, such as haemorrhagic fever viruses, could be infectious at levels well below the limit of detection afforded by current technologies. Because the human innate immune system is an exquisitely refined, highly sensitive and highly specific detection system for pathogens, monitoring changes in host innate response via biomarkers is a novel method for identifying exposure to biowarfare agents at very early time points. 


\section{Challenges and future trends}

The work reviewed in this manuscript provides evidence that the scientific community has not turned a blind eye to countering biothreat agents, but has responded with a massive effort that has resulted in a steep and productive learning curve. This effort has been facilitated by timely and significant increases in support from funding agencies. However, there is a serious lack of organization in how biodefence is currently addressed. Our existing preparedness and response measures are not sufficient to meet the challenges of a bioterrorist attack ${ }^{158}$. This is due not only to a lack of cooperation and coordination, but also to ineffective detection networks, a lack of time-effective diagnostic methodologies and the dearth of a clear vision and strategy to translate all of the publicly funded biodefence research into useful therapies and antidotes. These issues can be easily mitigated with a unified plan of action, orchestrated by a central entity overseeing a comprehensive and organized approach to biodefence. We foresee such a central entity playing a pivotal role in ensuring that cross-communication between agencies is facilitated, and that research is focused and completed in a timely manner. In addition, as potential new therapeutics emerge from the drug discovery pipeline, greater involvement from the pharmaceutical industry will be required. It is an accepted fact that the industry is adept at translational research — that is, rapidly and effectively converting potential therapies into approved drugs. However, incentives will need to be put in place to encourage the pharmaceutical industry to conduct such costly studies, and this is where a unifying biodefence entity can have a major facilitating role. Presently, project Bioshield is a start, but needs serious improvements. The ability to develop new therapeutics, and their approval as drugs that can be strategically stockpiled, is urgent. However, new technologies for detecting the release of biothreat agents, and timely protocols for the specific diagnosis of a biothreat agent that has been used, will be needed; this in turn could prevent the chaos that was experienced during the anthrax attacks of 2001. If we start making plans today, and unify our efforts, it will be possible to create a true biodefence shield that will effectively curtail future acts of bioterror.
1. Duesbery, N. S. et al. Proteolytic inactivation of MAP-kinasekinase by anthrax lethal factor. Science $\mathbf{2 8 0}, \mathbf{7 3 4 - 7 3 7}$ (1998).

2. Vitale, G. et al. Anthrax lethal factor cleaves the N-terminus of MAPKKs and induces tyrosine/threonine phosphorylation of MAPKs in cultured macrophages. Biochem. Biophys. Res. Commun. 248, 706-711 (1998).

3. Drum, C. L. et al. Structural basis for the activation of anthrax adenylyl cyclase exotoxin by calmodulin. Nature 415, 396-402 (2002).

4. Scobie, H. M., Rainey, G. J., Bradley, K. A. \& Young, J. A. Human capillary morphogenesis protein 2 functions as an anthrax toxin receptor. Proc. Natl Acad. Sci. USA 100, 5170-5174 (2003).

5. Bradley, K. A., Mogridge, J., Mourez, M., Collier, R. J. \& Young, J. A. Identification of the cellular receptor for anthrax toxin. Nature 414, 225-229 (2001).

6. Santelli, E., Bankston, L. A., Leppla, S. H. \& Liddington, R. C. Crystal structure of a complex between anthrax toxin and its host cell receptor. Nature 430, 905-908 (2004).

7. Klimpel, K. R., Molloy, S. S., Thomas, G. \& Leppla, S. H. Anthrax toxin protective antigen is activated by a cell surface protease with the sequence specificity and catalytic properties of furin. Proc. Natl Acad. Sci. USA 89, 10277-10281 (1992)

8. Cameron, A., Appel, J., Houghten, R. A. \& Lindberg, Polyarginines are potent furin inhibitors. J. Biol. Chem. 275 36741-36749 (2000)

9. Sarac, M. S., Peinado, J. R., Leppla, S. H. \& Lindberg, I. Protection against anthrax toxemia by hexa-D-arginine in vitro and in vivo. Infect. Immun. 72, 602-605 (2004).

10. Kacprzak, M. M. et al. Inhibition of furin by polyargininecontaining peptides: nanomolar inhibition by nona-口arginine. J. Biol. Chem. 279, 36788-36794 (2004).

11. Sellman, B. R., Mourez, M. \& Collier, R. J. Dominantnegative mutants of a toxin subunit: an approach to therapy of anthrax. Science 292, 695-697 (2001).

12. Singh, Y., Khanna, H., Chopra, A. P. \& Mehra, V. A dominant negative mutant of Bacillus anthracis protective antigen inhibits anthrax toxin action in vivo. J. Biol. Chem. 276, 22090-22094 (2001)

13. Mourez, M. et al. Designing a polyvalent inhibitor of anthrax toxin. Nature Biotechnol. 19, 958-961 (2001).

14. Nguyen, T. L. Three-dimensional model of the pore form of anthrax protective antigen. Structure and biological implications. J. Biomol. Struct. Dyn. 22, 253-265 (2004).

15. Hammond, S. E. \& Hanna, P. C. Lethal factor active-site mutations affect catalytic activity in vitro. Infect. Immun. 66, 2374-2378 (1998)

16. Tonello, F., Seveso, M., Marin, O., Mock, M. \& Montecucco, C. Screening inhibitors of anthrax lethal factor. Nature $\mathbf{4 1 8}$, 386 (2002).
17. Turk, B. E et al. The structural basis for substrate and inhibitor selectivity of the anthrax lethal factor. Nature Struct. Mol. Biol. 11, 60-66 (2004)

18. Cummings, R. T. et al. A peptide-based fluorescence resonance energy transfer assay for Bacillus anthracis lethal factor protease. Proc. Nat/ Acad. Sci. USA 99, 6603-6606 (2002).

This study and reference 17 describe peptide substrates for lethal factor and have greatly facilitated the identification of therapeutics against anthrax lethal toxin

9. Panchal, R. G. et al. Identification of small molecule inhibitors of anthrax lethal factor. Nature Struct. Mol. Biol. 11, 67-72 (2004).

This paper describes the first small molecule (nonpeptidic) inhibitors of LF, and includes X-ray co-crystal data of the most potent of the discovered compounds bound within the LF substrate binding cleft.

20. Min, D. H., Tang, W. J. \& Mrksich, M. Chemical screening by mass spectrometry to identify inhibitors of anthrax lethal factor. Nature Biotechnol. 22, 717-723 (2004).

21. Dell'Aica, I. et al. Potent inhibitors of anthrax lethal factor from green tea. EMBO Rep. 5, 418-422 (2004).

22. Lee, L. V. et al. Inhibition of the proteolytic activity of anthrax lethal factor by aminoglycosides. J. Am. Chem. Soc. 126, 4774-4775 (2004).

23. Soelaiman, S. et al. Structure-based inhibitor discovery against adenylyl cyclase toxins from pathogenic bacteria that cause anthrax and whooping cough. J. Biol. Chem 278, 25990-25997 (2003).

24. Shen, Y. et al. Selective inhibition of anthrax edema factor by adefovir, a drug for chronic hepatitis B virus infection. Proc. Natl Acad. Sci. USA 101, 3242-3247 (2004). This research describes how an existing, FDA approved drug was found to be a highly potent inhibitor of anthrax edema factor. Such 'drug recycling' represents a highly efficient means of fasttracking new treatments against biological weapons.

25. Paddle, B. M. Therapy and prophylaxis of inhaled biological toxins. J. Appl. Toxicol. 23, 139-170 (2003). A good review of inhaled biological toxin toxicities, host responses, and mechanisms of action.

26. Rainey, G. J. \& Young, J. A. Antitoxins: novel strategies to target agents of bioterrorism. Nature Rev. Microbiol. 2. 721-726 (2004) An excellent resource for reviewing the mechanisms of action of several biological toxins.

27. Dong, M. et al. Synaptotagmins I and || mediate entry of botulinum neurotoxin B into cells. J. Cell. Biol. 162 1293-1303 (2003).

28. Yowler, B. C., Kensinger, R. D. \& Schengrund, C. L. Botulinum neurotoxin $A$ activity is dependent upon the presence of specific gangliosides in neuroblastoma cells expressing synaptotagmin I. J. Biol. Chem. 277, 32815-32819 (2002)

29. Arnon, S. S. et al. Botulinum toxin as a biological weapon: medical and public health management. JAMA $\mathbf{2 8 5}$ 1059-1070 (2001).

30. Singh, B. R. Intimate details of the most poisonous poison. Nature Struct. Biol. 7, 617-619 (2000).

31. Turton, K., Chaddock, J. A. \& Acharya, K. R. Botulinum and tetanus neurotoxins: structure, function and therapeutic utility. Trends Biochem. Sci. 27, 552-558 (2002). Provides a good overview of botulinum neurotoxin structure, function, and medical applications.

32. Deshpande, S. S., Sheridan, R. E. \& Adler, M. Efficacy of certain quinolines as pharmacological antagonists in botulinum neurotoxin poisoning. Toxicon 35, 433-445 (1997)

33. Sheridan, R. E., Deshpande, S. S., Nicholson, J. D. \& Adler, M. Structural features of aminoquinolines necessary for antagonist activity against botulinum neurotoxin. Toxicon 35 1439-1451 (1997)

34. Eswaramoorthy, S., Kumaran, D. \& Swaminathan, S Crystallographic evidence for doxorubicin binding to the receptor-binding site in Clostridium botulinum neurotoxin B. Acta Crystallogr. D Biol. Crystallogr. 57, 1743-1746 (2001).

35. Hayden, J., Pires, J., Roy, S., Hamilton, M. \& Moore, G. J. Discovery and design of novel inhibitors of botulinus neurotoxin A: targeted 'hinge' peptide libraries. J. Appl. Toxicol. 23, 1-7 (2003).

36. Schmidt, J. J. \& Stafford, R. G. A high-affinity competitive inhibitor of type A botulinum neurotoxin protease activity. FEBS Lett. 532, 423-426 (2002).

37. Schmidt, J. J. \& Bostian, K. A. Proteolysis of synthetic peptides by type A botulinum neurotoxin. J. Protein Chem. 14, 703-708 (1995)

This work describes several peptide substrates for botulinum toxin serotype $A$ with major implications for the identification of therapeutics for other botulinum neurotoxins.

38. Schmidt, J. J. \& Bostian, K. A. Endoproteinase activity of type $A$ botulinum neurotoxin: substrate requirements and activation by serum albumin. J. Protein Chem. 16, 19-26 (1997).

39. Schmidt, J. J., Stafford, R. G. \& Bostian, K. A. Type A botulinum neurotoxin proteolytic activity: development of competitive inhibitors and implications for substrate specificity at the S1' binding subsite. FEBS Lett. 435, 61-64 (1998).

40. Sukonpan, C. et al. Synthesis of substrates and inhibitors of botulinum neurotoxin type A metalloprotease. J. Pept. Res. 63, 181-193 (2004)

41. Burnett, J. C. et al. Novel small molecule inhibitors of botulinum neurotoxin A metalloprotease activity. Biochem. Biophys. Res. Commun. 310, 84-93 (2003). 
The first small molecule (non-peptidic) inhibitors of botulinum neurotoxin serotype $A$ are described, and pharmacophore for inhibition is proposed.

42. Segelke, B., Knapp, M., Kadkhodayan, S., Balhorn, R. \& Rupp, B. Crystal structure of Clostridium botulinum neurotoxin protease in a product-bound state: Evidence for noncanonical zinc protease activity. Proc. Natl Acad. Sci. USA 101, 6888-6893 (2004).

43. Lacy, D. B., Tepp, W., Cohen, A. C., DasGupta, B. R. \& Stevens, R. C. Crystal structure of botulinum neurotoxin type A and implications for toxicity. Nature Struct. Biol. $\mathbf{5}$, 898-902 (1998).

44. Breidenbach, M. A. \& Brunger, A. T. Substrate recognition strategy for botulinum neurotoxin serotype A. Nature $\mathbf{4 3 2}$, 925-929 (2004)

45. Zhou, J. Y., Wang, Z. F., Ren, X. M., Tang, M. Z. \& Shi, Y. L. Antagonism of botulinum toxin type A-induced cleavage of SNAP-25 in rat cerebral synaptosome by toosendanin. FEBS Lett. 555, 375-379 (2003).

46. Adler, M., Nicholson, J. D., Cornille, F. \& Hackley, B. E., Jr. Efficacy of a novel metalloprotease inhibitor on botulinum neurotoxin B activity. FEBS Lett. 429, 234-238 (1998).

47. Eswaramoorthy, S., Kumaran, D. \& Swaminathan, S. A novel mechanism for Clostridium botulinum neurotoxin inhibition. Biochemistry 41, 9795-9802 (2002).

48. Adler, M. et al. Evaluation of phosphoramidon and three synthetic phosphonates for inhibition of botulinum neurotoxin B catalytic activity. J. Appl. Toxicol. 19 (Suppl. 1), S5-S11 (1999).

49. Garcia, G. E., Moorad, D. R. \& Gordon, R. K. Buforin I, a natural peptide, inhibits botulinum neurotoxin B activity in vitro. J. Appl. Toxicol. 19 (Suppl. 1), S19-S22 (1999).

50. Schmidt, J. J. \& Stafford, R. G. Fluorigenic substrates for the protease activities of botulinum neurotoxins, serotypes A, B, and F. Appl. Environ. Microbiol. 69, 297-303 (2003).

51. Roques, B. P., Anne, C., Turcaud, S. \& Fournie-Zaluski, M. C. Mechanism of action of clostridial neurotoxins and rational inhibitor design. Biol. Cell. 92, 445-447 (2000).

52. Anne, C. et al. Development of potent inhibitors of botulinum neurotoxin type B. J. Med. Chem. 46, 4648-4656 (2003).

53. Anne, C. et al. Thio-derived disulfides as potent inhibitors of botulinum neurotoxin type B: implications for zino interaction. Bioorg. Med. Chem. 11, 4655-4660 (2003).

54. Blommaert, A., Turcaud, S., Anne, C. \& Roques, B. P. Smal tripeptide surrogates with low nanomolar affinity as potent inhibitors of the botulinum neurotoxin B metallo-proteolytic activity. Bioorg. Med. Chem. 12, 3055-3062 (2004).

55. Monzingo, A. F. \& Robertus, J. D. X-ray analysis of substrate analogs in the ricin A-chain active site. J. Mol. Biol. 227, 1136-1145 (1992)

56. Yan, X. et al. Structure-based identification of a ricin inhibitor. J. Mol. Biol. 266, 1043-1049 (1997).

57. Miller, D. J., Ravikumar, K Shen, H., Suh, J.K. Kenwin S. M., Robertus, J. D. Structure-based design and characterization of novel platforms for ricin and shiga toxin inhibition. J. Med. Chem. 45, 90-98 (2002).

58. Nimjee, S. M., Rusconi, C. P. \& Sullenger, B. A. APTAMERS: an emerging class of therapeutics. Annu. Rev. Med. $\mathbf{5 6}$ 555-583 (2005)

The review gives and account of the evolution of aptamers as therapeutics and speculates on the clinical usefulness of these compounds.

59. Hesselberth, J. R., Miller, D., Robertus, J. \& Ellington, A. D. In vitro selection of RNA molecules that inhibit the activity of ricin A-chain. J. Biol. Chem. 275, 4937-4942 (2000).

60. Tanaka, K. S. et al. Ricin A-chain inhibitors resembling the oxacarbenium ion transition state. Biochemistry $\mathbf{4 0}$ 6845-6851 (2001)

61. Chen, X. Y., Link, T. M. \& Schramm, V. L. Ricin A-chain: kinetics, mechanism, and RNA stem-loop inhibitors. Biochemistry 37, 11605-11613 (1998)

62. Schlievert, P. M. Use of intravenous immunoglobulin in the treatment of staphylococcal and streptococcal toxic shock syndromes and related illnesses. J. Allergy Clin. Immunol. 108, S107-S110 (2001)

63. LeClaire, R. D., Kell, W., Bavari, S., Smith, T. J. \& Hunt, R. E. Protective effects of niacinamide in staphylococca enterotoxin-B-induced toxicity. Toxicology 107, 69-81 (1996).

64. Tarkowski, A. et al. Microbial superantigens as virulence factors and ways to counteract their actions. Scand. $U$. Infect. Dis. 35, 642-646 (2003).

65. Kieke, M. C. et al. High affinity T cell receptors from yeast display libraries block T cell activation by superantigens. J. Mol. Biol. 307, 1305-1315 (2001)

66. Hong-Geller, E. \& Gupta, G. Therapeutic approaches to superantigen-based diseases: a review. J. Mol. Recognit. 16, 91-101 (2003).
67. Shailubhai, K. Bioterrorism: a new frontier for drug discovery and development. IDrugs 6, 773-780 (2003).

68. Kaempfer, R. Peptide antagonists of superantigen toxins. Mol. Divers. 8, 113-120 (2004).

69. Rajagopalan, G., Sen, M. M. \& David, C. S. In vitro and in vivo evaluation of staphylococcal superantigen peptide antagonists. Infect. Immun. 72, 6733-6737 (2004).

70. Arad, G., Levy, R., Hillman, D. \& Kaempfer, R. Superantigen antagonist protects against lethal shock and defines a new domain for T-cell activation. Nature Med. 6, 414-421 (2000).

71. De Clercq, E. Antiviral drugs in current clinical use. J. Clin. Virol. 30, 115-133 (2004)

\section{Review that covers antiviral drugs in clinical use.}

72. Chan, S. Y. et al. Folate receptor- $\alpha$ is a cofactor for cellular entry by Marburg and Ebola viruses. Cell 106, 117-126 (2001).

73. Becker, S., Spiess, M. \& Klenk, H. D. The asialoglycoprotein receptor is a potential liver-specific receptor for Marburg virus. J. Gen. Virol. 76 (Pt 2), 393-399 (1995)

74. Takada, A. et al. Human macrophage C-type lectin specific for galactose and $\mathrm{N}$-acetylgalactosamine promotes filovirus entry. J. Virol. 78, 2943-2947 (2004).

75. Simmons, G. et al. DC-SIGN and DC-SIGNR bind ebola glycoproteins and enhance infection of macrophages and endothelial cells. Virology 305, 115-123 (2003).

76. Barrientos, L. G. \& Gronenborn, A. M. The highly specific carbohydrate-binding protein cyanovirin-n: structure, antiHIV/ebola activity and possibilities for therapy. Mini. Rev. Med. Chem. 5, 21-31 (2005).

77. Harrison, S. C. et al. Discovery of antivirals against smallpox Proc. Natl Acad. Sci. USA 101, 11178-11192 (2004).

78. Watanabe, S. et al. Functional importance of the coiled-col of the Ebola virus glycoprotein. J. Virol. 74, 10194-10201 (2000).

79. Weissenhorn, W., Calder, L. J., Wharton, S. A., Skehel, J. J. \& Wiley, D. C. The central structural feature of the membrane fusion protein subunit from the Ebola virus glycoprotein is a long triple-stranded coiled coil. Proc. Nat Acad. Sci. USA 95, 6032-6036 (1998).

80. Weissenhorn, W., Carfi, A., Lee, K. H., Skehel, J. J. \& Wiley, D. C. Crystal structure of the Ebola virus membrane fusion subunit, GP2, from the envelope glycoprotein ectodomain. Mol. Cell 2, 605-616 (1998).

81. Aman, M. J. et al. Molecular mechanisms of filovirus cellular trafficking. Microbes Infect. 5, 639-649 (2003).

82. Goodchild, J. Oligonucleotide, antibody and peptide therapeutics - from design to the clinic. Curr. Opin. Mol. Ther. 6, 119 (2004).

83. Muhlberger, E., Weik, M., Volchkov, V. E., Klenk, H. D. \& Becker, S. Comparison of the transcription and replication strategies of marburg virus and Ebola virus by using artificial replication systems. J. Virol. 73, 2333-2342 (1999).

84. Towner, J. S. et al. Generation of eGFP expressing recombinant Zaire ebolavirus for analysis of early pathogenesis events and high-throughput antiviral drug screening. Virology 332, 20-27 (2005).

85. Siegert, R., Shu, H. L. \& Slenczka, W. Isolation and identification of the 'Marbury virus'. Ger. Med. Mon. 13 514-518 (1968)

86. Geisbert, T. W. \& Jahrling, P. B. Differentiation of filoviruses by electron microscopy. Virus Res. 39, 129-150 (1995).

87. Bavari, S. et al. Lipid raft microdomains: a gateway for compartmentalized trafficking of Ebola and Marburg viruses. J. Exp. Med. 195, 593-602 (2002).

88. Neumann, G., Feldmann, H., Watanabe, S., Lukashevich, I. \& Kawaoka, Y. Reverse genetics demonstrates that proteolytic processing of the Ebola virus glycoprotein is not essential for replication in cell culture. J. Virol. 76, 406-410 (2002).

89. Cono, J., Casey, C. G. \& Bell, D. M. Smallpox vaccination and adverse reactions. Guidance for clinicians. MMWR Recomm. Rep. 52, 1-28 (2003).

90. Geisbert, T. W. et al. Mechanisms underlying coagulation abnormalities in ebola hemorrhagic fever: overexpression of issue factor in primate monocytes/macrophages is a key event. J. Infect. Dis. 188, 1618-1629 (2003).

91. Geisbert, T. W. et al. Treatment of Ebola virus infection with a recombinant inhibitor of factor Vlla/tissue factor: a study in rhesus monkeys. Lancet 362, 1953-1958 (2003). This is one of the first examples of host-directed therapeutics for filoviruses. The report suggests the therapeutic targeting of the sequential lifecycles of pathogenic filoviruses, such as the coagulation processes, may have beneficial outcomes.

92. Schmaljohn, A. L., Johnson, E. D., Dalrymple, J. M. \& Cole, G. A. Non-neutralizing monoclonal antibodies can prevent lethal alphavirus encephalitis. Nature 297, 70-72 (1982).
93. Hart, M. K. Vaccine research efforts for filoviruses. Int $J$ Parasitol 33, 583-595 (2003).

94. Hevey, M., Negley, D., Geisbert, J., Jahrling, P. \& Schmaljohn, A. Antigenicity and vaccine potential of Marburg virus glycoprotein expressed by baculovirus recombinants. Virology 239, 206-216 (1997).

95. Hevey, M., Negley, D. \& Schmaljohn, A. Characterization of monoclonal antibodies to Marburg virus (strain Musoke) glycoprotein and identification of two protective epitopes. Virology 314, 350-357 (2003)

96. Wilson, J. A. et al. Epitopes involved in antibody-mediated protection from Ebola virus. Science 287, 1664-1666 (2000)

The first report of a monoclonal antibody treatment for ebola virus that showed in vivo protection.

97. Jahrling, P. B. et al. Passive immunization of Ebola virusinfected cynomolgus monkeys with immunoglobulin from hyperimmune horses. Arch. Virol. Suppl. 11, 135-140 (1996).

98. Hevey, M., Negley, D., Pushko, P., Smith, J. \& Schmaljohn, A. Marburg virus vaccines based upon alphavirus replicons protect guinea pigs and nonhuman primates. Virology $\mathbf{2 5 1}$ 28-37 (1998)

The first demonstration of an efficacious vaccine against filoviruses.

99. Ignatyev, G. M. Immune response to filovirus infections. Curr. Top. Microbiol. Immunol. 235, 205-217 (1999).

100. Vanderzanden, L. et al. DNA vaccines expressing either the GP or NP genes of Ebola virus protect mice from letha challenge. Virology 246, 134-144 (1998).

101. Wilson, J. A. \& Hart, M. K. Protection from Ebola virus mediated by cytotoxic T lymphocytes specific for the vira nucleoprotein. J. Virol. 75, 2660-2664 (2001).

102. Xu, L. et al. Immunization for Ebola virus infection. Nature Med. 4, 37-42 (1998).

103. Martini, G. A. a. R. S. Marburg Virus Disease (Springer-Verlag, Berlin New York, 1971)

104. Mupapa, K et al. Treatment of Ebola hemorrhagic fever with blood transfusions from convalescent patients. Internationa Scientific and Technical Committee. J. Infect. Dis. 179 (Suppl. 1), S18-S23 (1999).

105. Boulter, E. A. \& Appleyard, G. Differences between extracellular and intracellular forms of poxvirus and their implications. Prog. Med. Virol. 16, 86-108 (1973).

106. Hooper, J. W., Custer, D. M., Schmaljohn, C. S. \& Schmaljohn, A. L. DNA vaccination with vaccinia virus L1R and $A 33 R$ genes protects mice against a lethal poxvirus challenge. Virology 266, 329-339 (2000).

107. Hooper, J. W. et al. Smallpox DNA vaccine protects nonhuman primates against lethal monkeypox. J. Virol. $\mathbf{7 8}$ 4433-4443 (2004).

108. Galmiche, M. C., Goenaga, J., Wittek, R. \& Rindisbacher, L. Neutralizing and protective antibodies directed against vaccinia virus envelope antigens. Virology 254, 71-80 (1999).

109. Schmaljohn, A. L., Kokubun, K. M. \& Cole, G. A. Protective monoclonal antibodies define maturational and $\mathrm{pH}$ dependent antigenic changes in Sindbis virus E1 glycoprotein. Virology 130, 144-154 (1983).

110. Bell, E. et al. Antibodies against the extracellular enveloped virus B5R protein are mainly responsible for the EEV neutralizing capacity of vaccinia immune globulin. Virology 325, 425-431 (2004)

111. Mohamadzadeh, M. \& Luftig, R. Dendritic cells: in the forefront of immunopathogenesis and vaccine development - a review. J. Immune Based Ther. Vaccines 2, 1 (2004).

112. Palese, P., Muster, T., Zheng, H., O'Neill, R. \& Garcia-Sastre, A. Learning from our foes: a novel vaccine concept for influenza virus. Arch. Virol. Suppl. 15, 131-138 (1999).

113. Chang, H. W., Watson, J. C. \& Jacobs, B. L. The E3L gene of vaccinia virus encodes an inhibitor of the interferoninduced, double-stranded RNA-dependent protein kinase. Proc. Natl Acad. Sci. USA 89, 4825-4829 (1992)

114. Basler, C. F. et al. The Ebola virus VP35 protein functions as a type I IFN antagonist. Proc. Natl Acad. Sci. USA 97, 12289-12294 (2000).

115. Bosio, C. M. et al. Ebola and Marburg viruses replicate in monocyte-derived dendritic cells without inducing the production of cytokines and full maturation. J. Infect. Dis. 188, 1630-1638 (2003)

116. Seet, B. T. et al. Poxviruses and immune evasion. Annu. Rev. Immunol. 21, 377-423 (2003).

117. Warfield, K. L. et al. Ebola virus-like particles protect from lethal Ebola virus infection. Proc. Natl Acad. Sci. USA 100 15889-15894 (2003)

118. Pornillos, O., Garrus, J. E. \& Sundquist, W. I. Mechanisms of enveloped RNA virus budding. Trends Cell Biol. 12. 569-579 (2002). 
119. Moss, B. \& Ward, B. M. High-speed mass transit for poxviruses on microtubules. Nature Cell Biol. 3, E245-E246 (2001)

120. Bieniasz, P. Intrinsic immunity: a front-line defense against viral attack. Nature Immunol. 5, 1109-1115 (2004).

121. Grandvaux, N., tenOever, B. R., Servant, M. J. \& Hiscott, J. The interferon antiviral response: from viral invasion to evasion. Curr. Opin. Infect. Dis. 15, 259-267 (2002).

122. Heine H., D. R. a. A. G. in 41st Interscience Conference on Antimicrobial Agents and Chemotherapy (Chicago, IL, 2001).

123. Heine H., D. R. a. B. W. in 40th Interscience Conference on Antimicrobial Agents and Chemotherapy (Toronto, Canada, 2000).

124. Inglesby, T. V. et al. Anthrax as a biological weapon, 2002 updated recommendations for management. JAMA 287 2236-2252 (2002).

125. Bartlett, J. G., Inglesby, T. V., Jr. \& Borio, L. Management of anthrax. Clin. Infect. Dis. 35, 851-858 (2002).

126. Pomerantsev, A. P., Shishkova, N. A. \& Marinin, L. I. [Comparison of therapeutic effects of antibiotics of the tetracycline group in the treatment of anthrax caused by a strain inheriting tet-gene of plasmid pBC16]. Antibiot. Khimioter. 37, 31-34 (1992)

127. Stepanov, A. V., Marinin, L. I., Pomerantsev, A. P. \& Staritsin, N. A. Development of novel vaccines against anthrax in man. J. Biotechnol. 44, 155-160 (1996).

128. Vasi'lev, N. T. et al. [Sensitivity spectrum of Francisella tularensis to antibiotics and synthetic antibacterial drugs] Antibiot. Khimioter. 34, 662-665 (1989).

129. Scheel, O., Hoel, T., Sandvik, T. \& Berdal, B. P. Susceptibility pattern of Scandinavian Francisella tularensis isolates with regard to oral and parenteral antimicrobial agents. APMIS 101, 33-36 (1993)

130. Maurin, M., Mersali, N. F. \& Raoult, D. Bactericidal activities of antibiotics against intracellular Francisella tularensis. Antimicrob. Agents Chemother. 44, 3428-3431 (2000).

131. Kudelina, R. I. \& Olsufiev, N. G. Sensitivity to macrolide antibiotics and lincomycin in Francisella tularensis holarctica. J. Hyg. Epidemiol. Microbiol. Immunol. 24 84-91 (1980).

132. Ikaheimo, I., Syrjala, H., Karhukorpi, J., Schildt, R. \& Koskela, M. In vitro antibiotic susceptibility of Francisella tularensis isolated from humans and animals. J. Antimicrob. Chemother. 46, 287-290 (2000).

133. Baker, C. N., Hollis, D. G. \& Thornsberry, C. Antimicrobial susceptibility testing of Francisella tularensis with a modified Mueller-Hinton broth. J. Clin. Microbiol. 22, 212-215 (1985)

134. Dennis, D. T. et al. Tularemia as a biological weapon: medical and public health management. JAMA $\mathbf{2 8 5}$ 2763-73 (2001)

135. Ellis, J., Oyston, P. C., Green, M. \& Titball, R. W. Tularemia. Clin. Microbiol. Rev. 15, 631-646 (2002).

136. Perez-Castrillon, J. L., Bachiller-Luque, P., Martin-Luquero, M., Mena-Martin, F. J. \& Herreros, V. Tularemia epidemic in northwestern Spain: clinical description and therapeutic response. Clin. Infect. Dis. 33, 573-576 (2001).

137. Henchal, E. A., Teska, J. D., Ludwig, G. V., Shoemaker, D. R. \& Ezzell, J. W. Current laboratory methods for biological threat agent identification. Clin. Lab. Med. 21, 661-678 (2001).

138. Gilchrist, M. J. A national laboratory network for bioterrorism: evolution from a prototype network of laboratories performing routine surveillance. Mil. Med. 165 28-31 (2000)

139. Gilchrist, M. J. R., W. P. McKinney, J. M. Miller, and A. S. Weissfeld. Laboratory safety, management and diagnosis of biological agents associated with bioterrorism (ed Snyder, J. W.) (ASM Press, Washington, DC, 2000).

140. Jernigan, D. B. et al. Investigation of bioterrorism-related anthrax, United States, 2001: epidemiologic findings. Emerg. Infect. Dis. 8, 1019-1028 (2002).

141. Jernigan, J. A. et al. Bioterrorism-related inhalational anthrax: the first 10 cases reported in the United States. Emerg. Infect. Dis. 7, 933-944 (2001).

142. (Health Alert Network, 2003)

143. Marburg, J. in Biosecurity 2003 (Washington, DC, 2003).

144. (National Association of Letter Carriers, 2003).

145. In U. S. Senate Committee on Environment and Public Works (Environmental Protection Agency, 2001).

146. Sirisanthana, T., Nelson, K. E., Ezzell, J. W. \& Abshire, T. G. Serological studies of patients with cutaneous and oraloropharyngeal anthrax from northern Thailand. Am. J. Trop. Med. Hyg. 39, 575-581 (1988)

147. Hofstadler, S. A. et al. TIGER: the universal biosensor. Intl J. Mass Spectrometry 12844, 1-18 (2004).
148. Kasianowicz, J. J. \& Bezrukov, S. M. Protonation dynamics of the alpha-toxin ion channel from spectral analysis of $\mathrm{pH}$ dependent current fluctuations. Biophys. J. 69, 94-105 (1995).

149. Kasianowicz, J. J., Brandin, E., Branton, D. \& Deamer, D. W. Characterization of individual polynucleotide molecules using a membrane channel. Proc. Natl Acad. Sci. USA 93 13770-13773 (1996).

150. Kasianowicz, J. J., Henrickson, S. E., Weetall, H. H. \& Robertson, B. Simultaneous multianalyte detection with a nanometer-scale pore. Anal. Chem. 73, 2268-2272 (2001).

Describes how nanopores might be able to act as biosensors. This technology has incredible potential as a bioagent sensor.

151. Relman, D. A. Genome-wide responses of a pathogenic bacterium to its host. J. Clin. Invest. 110, 1071-1073 (2002)

152. Relman, D. A. Shedding light on microbial detection. N. Engl. J. Med. 349, 2162-2163 (2003).

153. Davies, D. H. et al. Profiling the humoral immune response to infection by using proteome microarrays: Highthroughput vaccine and diagnostic antigen discovery. Proc. Natl Acad. Sci. USA 102, 547-552 (2005).

154. Hertel, L. \& Mocarski, E. S. Global analysis of host cell gene expression late during cytomegalovirus infection reveals extensive dysregulation of cell cycle gene expression and induction of Pseudomitosis independent of US28 function. J. Virol. 78, 11988-12011 (2004).

155. Kobayashi, S. D. et al. Bacterial pathogens modulate an apoptosis differentiation program in human neutrophils. Proc. Natl Acad. Sci. USA 100, 10948-10953 (2003). Shows how innate immune cells can be used as early host-directed diagnosis and how various pathogens alter early responding cells.

156. Rubins, K. H. et al. The host response to smallpox: analysis of the gene expression program in peripheral blood cells in a nonhuman primate model. Proc. Natl Acad. Sci. USA 101 15190-15195 (2004).

157. Waters, M. D. \& Fostel, J. M. Toxicogenomics and systems toxicology: aims and prospects. Nature Rev. Genet. $\mathbf{5}$ 936-948 (2004)

A good review on the field of toxicogenomics and explains how this field is evolving.

158. Gilfillan, L. et al. Taking the measure of countermeasures: leaders' views on the nation's capacity to develop biodefense countermeasures. Biosecur. Bioterror. 2 320-327 (2004).

Debates our readiness against a bioterrorist attack and reports the views of several key leaders regarding our capacity to develop solid biodefence countermeasures.

159. Mahanty, S. \& Bray, M. Pathogenesis of filoviral haemorrhagic fevers. Lancet Infect. Dis. 4, 487-498 (2004). An in-depth review of filoviruses life cycle and pathogenisis.

160. Borio, L. et al. Hemorrhagic fever viruses as biological weapons: medical and public health management. JAMA 287, 2391-2405 (2002)

161. Bausch, D. G. et al. Risk factors for Marburg hemorrhagic fever, Democratic Republic of the Congo. Emerg. Infect. Dis. 9, 1531-1537 (2003).

162. Leroy, E. M. et al. Multiple Ebola virus transmission events and rapid decline of central African wildlife. Science $\mathbf{3 0 3}$ 387-390 (2004)

63. Feldmann, H., Jones, S., Klenk, H. D. \& Schnittler, H. J. Ebola virus: from discovery to vaccine. Nature Rev. Immunol. 3, 677-685 (2003)

164. Geisbert, T. W. \& Jahrling, P. B. Towards a vaccine against Ebola virus. Expert Rev. Vaccines 2, 777-789 (2003).

165. Levine, M. M. New Generation Vaccines (ed. Dekker, M.) (Taylor \& Francis, New York London, 2004).

166. Henderson, D. A. et al. Smallpox as a biological weapon: medical and public health management. Working Group on Civilian Biodefense. JAMA 281, 2127-2137 (1999).

167. Garbutt, M. et al. Properties of replication-competen vesicular stomatitis virus vectors expressing glycoproteins of filoviruses and arenaviruses. J. Virol. 78, 5458-5465 (2004).

168. Chen, R. T. \& Lane, J. M. Myocarditis: the unexpected return of smallpox vaccine adverse events. Lancet $\mathbf{3 6 2}$ 1345-1346 (2003).

169. Earl, P. L. et al. Immunogenicity of a highly attenuated MVA smallpox vaccine and protection against monkeypox. Nature 428, 182-185 (2004)

170. Hsu, V. P. et al. Opening a Bacillus anthracis-containing envelope, Capitol Hill, Washington, D. C. : the public health response. Emerg. Infect. Dis. 8, 1039-1043 (2002).
171. Friedlander, A. M. Textbook of Military Medecine (ed. Zajtchuk, R.) 467-478 (U. S. Department of the Army, Surgeon General and the Borden Institute, Washington, DC, 1997).

A good review on Bacillus anthracis pathogeneis.

172. Brachman, P. S. Inhalation anthrax. Ann. NY Acad. Sci. 353, 83-93 (1980).

173. Hail, A. S. et al. Comparison of noninvasive sampling sites for early detection of Bacillus anthracis spores from rhesus monkeys after aerosol exposure. Mil. Med. 164, 833-837 (1999)

174. Meltzer, M. I., Damon, I., LeDuc, J. W. \& Millar, J. D. Modeling potential responses to smallpox as a bioterrorist weapon. Emerg. Infect. Dis. 7, 959-969 (2001).

175. Sandvig, K. \& van Deurs, B. Transport of protein toxins into cells: pathways used by ricin, cholera toxin and Shiga toxin FEBS Lett. 529, 49-53 (2002).

176. Olsnes, S. \& Kozlov, J. V. Ricin. Toxicon 39, 1723-1728 (2001)

177. Endo, Y. \& Tsurugi, K. The RNA N-glycosidase activity of ricin A-chain. The characteristics of the enzymatic activity of ricin A-chain with ribosomes and with rRNA. J. Biol. Chem. 263, 8735-8739 (1988)

178. Lord, M. J. et al. Ricin. Mechanisms of cytotoxicity. Toxicol. Rev. 22, 53-64 (2003)

179. Endo, Y. \& Tsurugi, K. RNA N-glycosidase activity of ricin Achain. Mechanism of action of the toxic lectin ricin on eukaryotic ribosomes. J. Biol. Chem. 262, 8128-8130 (1987)

180. Greenfield, R. A. \& Bronze, M. S. Prevention and treatment of bacterial diseases caused by bacterial bioterrorism threat agents. Drug Discov. Today 8 , 881-888 (2003).

A good source for currently available prophylactics and treatments against bacterial bioweapons.

181. Kozel, T. R. et al. mAbs to Bacillus anthracis capsula antigen for immunoprotection in anthrax and detection of antigenemia. Proc. Natl Acad. Sci. USA 101, 5042-5047 (2004).

182. Little, S. F., Ivins, B. E., Fellows, P. F., Friedlander, A. M. \& 1997. Passive protection by polyclonal antibodies against Bacillus anthracis infection in guinea pigs. Infect. Immun. $\mathbf{6 5}$ 5171-5175.

183. Little, S. F., Leppla, S. H., \& Cora, E. Production and characterization of monoclonal antibodies to the protective antigen component of Bacillus anthracis toxin. Infect. Immun. 56, 1807-1813 (1988).

184. Maynard, J. A. et al. Protection against anthrax toxin by recombinant antibody fragments correlates with antigen affinity. Nature Biotechnol. 20, 597-601 (2002).

185. Sawada-Hirai, R. et al. Human anti-anthrax protective antigen neutralizing monoclonal antibodies derived from donors vaccinated with anthrax vaccine adsorbed. $J$. Immune Based Ther. Vaccines 2, 5 (2004).

186. Brown, D. R., Lloyd, J. P. \& Schmidt, J. J. Identification and characterization of a neutralizing monoclonal antibody against botulinum neurotoxin serotype $F$, following vaccination with active toxin. Hybridoma 16, 447-456 (1997).

187. Casadevall, A. Passive antibody administration (immediate immunity) as a specific defense against biological weapons. Emerg. Infect. Dis. 8, 833-841 (2002).

A review that covers antibody development for several biowarfare agents.

188. Chen, F. et al. Antibody mapping to domains of botulinum neurotoxin serotype $\mathrm{A}$ in the complexed and uncomplexed forms. Infect. Immun. 65, 1626-1630 (1997).

189. Ferreira, J. L., Hamdy, M. K., McCay, S. G. \& Zapatka, F. A. Monoclonal antibody to type $\mathrm{F}$ Clostridium botulinum toxin. Appl. Environ. Microbiol. 56, 808-811 (1990).

190. Kubota, T. et al. Epitope regions in the heavy chain of Clostridium botulinum type $\mathrm{E}$ neurotoxin recognized by monoclonal antibodies. Appl. Environ. Microbiol. 63 1214-1218 (1997)

191. Marks, J. D. Deciphering antibody properties that lead to potent botulinum neurotoxin neutralization. Mov Disord 19 (Suppl. 8), S101-S108 (2004).

192. Mullaney, B. P., Pallavicini, M. G. \& Marks, J. D. Epitope mapping of neutralizing botulinum neurotoxin $A$ antibodies by phage display. Infect. Immun. 69, 6511-654 (2001).

193. Nowakowski, A. et al. Potent neutralization of botulinum neurotoxin by recombinant oligoclonal antibody. Proc. Natl Acad. Sci. USA 99, 11346-11350 (2002).

194. Pless, D. D., Torres, E. R., Reinke, E. K. \& Bavari, S. Highaffinity, protective antibodies to the binding domain of botulinum neurotoxin type A. Infect. Immun. 69, 570-574 (2001). 
195. Chanh, T. C. \& Hewetson, J. F. Protection against ricin intoxication in vivo by anti-idiotype vaccination. Vaccine $\mathbf{1 3}$ 479-485 (1995).

196. Chanh, T. C., Romanowski, M. J. \& Hewetson, J. F. Monoclonal antibody prophylaxis against the in vivo toxicity of ricin in mice. Immunol. Invest. 22, 63-72 (1993).

197. Lemley, P. V., Amanatides, P. \& Wright, D. C. Identification and characterization of a monoclonal antibody that neutralizes ricin toxicity in vitro and in vivo. Hybridoma 13 417-421 (1994)

198. Lemley, P. V., Thalley, B. S. \& Stafford, D. C. Prophylactic and therapeutic efficacy of an avian antitoxin in ricin intoxication. Ther. Immunol. 2, 59-66 (1995).

199. Maddaloni, M. et al. Immunological characteristics associated with the protective efficacy of antibodies to ricin J. Immunol. 172, 6221-6228 (2004).

200. Olson, M. A. et al. Finding a new vaccine in the ricin protein fold. Protein Eng. Des. Sel. 17, 391-397 (2004).

201. Poli, M. A., Rivera, V. R., Pitt, M. L. \& Vogel, P. Aerosolized specific antibody protects mice from lung injury associated with aerosolized ricin exposure. Toxicon 34, 1037-44 (1996).
202. Smallshaw, J. E. et al. A novel recombinant vaccine which protects mice against ricin intoxication. Vaccine $\mathbf{2 0}$ 3422-3427 (2002).

203. LeClaire, R. D. \& Bavari, S. Human antibodies to bacterial superantigens and their ability to inhibit T-cell activation and lethality. Antimicrob. Agents Chemother. 45, 460-463 (2001).

204. LeClaire, R. D., Hunt, R. E. \& Bavari, S. Protection against bacterial superantigen staphylococcal enterotoxin $B$ by passive vaccination. Infect. Immun. 70, 2278-2281 (2002).

205. Burnett, J. C. et al. Conformational sampling of the botulinum neurotoxin serotype a light chain: implications for inhibitor binding. Bioorg. Med. Chem. 13, 333-341 (2005).

206. Franz, D. R in Textbook of Military Medicine (ed. Zaitchuk, B. 603-619 (US Department of the Army, Surgeon General and the Borden Institute, Washington DC, 1997).

Acknowledgements

The authors would like to thank M. J. Aman, R. Panchal, C. Whitehouse, B. Purcell, B. Stiles, R. Gussio and M. Hepburn fo critical comments and substantial help in preparing this review. T. L

Nguyen for generating figure 1. In addition, we sincerely apologise to our esteemed colleagues whose work could not be included in this review due to space limitations. The content of this review does not necessarily reflect the views or policies of the Department of Health and Human Services or US Army, nor does mention of trade names, commercial products or organizations imply endorsement by the US Government.

Competing interest statement

The authors declare no competing financial interests.

(2) Online links

\section{FURTHER INFORMATION}

Bioterrorism Resources:

http://www-library.ncifcrf.gov/bioterrorism.asp CDC Emergency Preparedness \& Response Site: http://www.bt.cdc.gov/

Centers for Disease Control: http://www.cdc.gov/ Developmental Therapeutics Program NCl/NIH:

http://dtp.nci.nih.gov/

US Army Medical Research Institute of Infectious Diseases:

http://www.usamriid.army.mil/

US Department of State: http://usinfo.state.gov/

Access to this interactive links box is free online. 